\title{
WHAT INFLUENCE DO THE OLD SÁMI NOAIDI DRUMS FROM LAPLAND PLAY IN THE CONSTRUCTION OF NEW SHAMAN DRUMS BY SÁMI PERSONS TODAY?
}

\author{
Francis Joy
}

\begin{abstract}
The suppressed history of the Sámi in Lapland contains within it large gaps which span across lost generations of religious specialists called Noaidi. The Noaidi in Sámi society was a healer, curer, diviner and ritual master. One of the important instruments associated with the work of the Noaidi is the magical drum referred to as goavddis, which was richly decorated with symbols and structures depicting an indigenous worldview and cosmic order. The art of the Noaidi has been one of the main inspirations and influences for the preservation of Sámi culture and heritage, to such an extent that new types of decorative 'Shaman' drums are emerging in Finnish and Norwegian Lapland. These new drums reflect both typologies and worldview of the Noaidi from the seventeenth and eighteenth centuries, and provide some level of insight how the transmission of culture continues today.
\end{abstract}

Key words: Sámi Noaidi, drum, divination, structure, shamanism, Lapland, new drums, symbolism, persecutions

\section{INTRODUCTION}

The Sámi are the indigenous people of Norway, Sweden, Finland and the Kola Peninsula in Russia who have lived as a hunting, fishing and reindeer herding culture for the past several thousand years. The Sámi areas in northern Scandinavia are known today as Sámi. Presently, the Sámi have their own language and culture. Sámi society still consists of traditional subsistence activities such as reindeer herding, hunting and fishing; traditional ways of organizing the society and its occupants are called Siida and land, which form a type of coherent narrative for the structures within Sámi society. Relations to the Siida and land are the pillars within society which have helped to transmit Sámi culture and identity in both a modern as well as historical context. Currently, throughout the Sámi areas in Finnish Lapland there are three languages spoken, North Sámi, Inari Sámi and Skolt Sámi. Tourism is an option of course 
but many Sámi work within the education and 'services' (school, health care, shops, restaurants), i.e. the modern sector of working life.

One of the colourful dimensions which is prominent from within the history of Sámi culture is a specific type of art created by persons called Noaidi's who are perhaps better known from outside Sámi society as shamans. The Sámi noaidi from the Pre-historic era as well as from the time when Christianity arrived in Lapland around the seventeenth and eighteenth centuries, have through tradition been persons' responsible for depicting metaphors and symbols from visions and out-of-body travelling to other worlds, via many natural forms of art which has come from a long standing oral tradition. For example, the earliest traces of work related to the noaidi, is encountered through prehistoric rock carvings and paintings found extensively throughout the Nordic countries and Kola Peninsula in Russia, indicating that the Sámi are a visual culture.

Scholarly research undertaken during the 1990s by Autio (1995), Nunez (1995) and Joy $(2011 ; 2013)$ has prompted further investigation by the author into what appears as evidence of significant a number of rock carvings from the Alta site in Finnmark, Norway and rock paintings from central and southern Finland from ancient hunting and fishing cultures. These sources of traditional knowledge which can be linked to Sámi identity and cultural Pre-history have strikingly similar motifs and figures that are also recognizable from amongst the nomadic art from Lapland painted on noaidi drums from the seventeenth and eighteenth centuries when the missionizing began. Rock carvings and paintings are situated close to water where they are depicted on flat and vertical stone terraces and boulder formations. Most sites display an array of different figures including animals, humans, spirits, lunar and solar symbols and geometric patterns and shapes. The reason for creating artwork close to the water's edge is because the shoreline may have represented a membrane between the physical and spiritual dimensions, a type of border region between the living and departed.

Like other indigenous peoples, the emotional and cultural ties to the past historical legacy of ancestors and interactions with spirits are recorded through art. The Sámi saw nature as a huge well of inspiration which provided a basis for decoration and expression of the spiritual aspects of the material culture. It is also common knowledge too amongst the Sámi, that in a past tense in Lapland, the noaidi has been the only person with the authority to paint the magical drum which has been a strong feature in relation to identity. Evidence and analysis of the nature of drum symbolism shows how the inspiration and knowledge has been drawn upon from interactions with the animal kingdom for building and decorating noaidi-shaman drums which are important sources of strength for the Sámi. The usage of symbols and the transmission of culture 
with regard to utilizing illustrations from rock carvings and paintings to noaidi drums shows how the symbols have played an essential role in strengthening and maintaining Sámi identity which has seen a radical shift into modern-urban life from the traditional hunting and fishing culture.

Before the Christian priests and missionary workers arrived in Lapland during colonialisation era of the seventeenth and eighteenth centuries, shamanism was the fundamental basis of a religious tradition that was rooted in a relationship with nature, ancestral and ruling spirits, and close ties with the animal kingdom. Due to the widespread conversion from a nature based religion to Christianity, there are beliefs from within the Lutheran Church in Finland that shamanism does not exist anymore in Lapland which is incorrect. By contrast and in Norwegian Lapland for example, in the municipalities of Kautokeino, Karasjok within the Finnmark area in the far north of the country, traces of the practice of shamanism and traditional Sámi healing are still evident today.

The cultural and religious upheavals caused by Christianity has encouraged extensive research into the nature and context of the persecutions which took place during the colonial era throughout the Nordic countries which saw noaidi drums confiscated and destroyed in their hundreds. Information presented from court records from the 17th century Witch trials in Norway for example from; the scholarly work of religious historian Rune Blix Hagan (2005; 2006) from the University of Tromso, Norway informs us of the following. Hagan states that the Sámi noaidi-shaman was one of the most feared and at the same time revered figures ever to have emerged from within the nomadic reindeer culture throughout Lapland. "From ancient times, the Lapland sorcerers had a strong reputation for wind magic, shape shifting (metamorphosis), employment of familiars, the ability to move objects (such as small darts) across great distances, and for their wicked drum playing" (Hagan 2006: 625). The description presented by Hagen is only one dimension to the position of the noaidi in Sámi society. On the other hand and when viewed in a different light, the noaidi was also a person who was an artist, ritual and visionary specialist, storyteller, healer, diviner and magician. As both men and women, the noaidi was also a bearer of tradition, and knowledge holder within Sámi society and inter-species communicator. The application of painted symbols to drums has been one of the main ways of recording stories and sacred narratives. The early portraits presented of noaidi's throughout Lapland, were compiled through distorted images by priests and missionaries to suit both the Swedish state and Churches political and religious agendas. Many of the sources (for example, see Schefferus 1674) speak about a culture in Lapland which was illuminated by spirits and ancient gods and goddesses of the sky, earth and realms below the earth and water called Säiva, described as a mythical underworld, as well 
as Jabma-Aimo, the world of the dead. Both Säiva and Jabma-Aimo appear to have very important destinations to where the noaidi travelled extensively, to communicate and work with spiritual beings with whom the noaidi, through sacrificial activities, trance and out-of-body travelling and with the aid of a drum, formed a working relationship with. On many of the old drums, images and structures of both Säiva and Jabma-Aimo stand out extensively, indicating that relations with the spirits in the afterlife have also played a functional role in Sámi society. It is the author's opinion, that one of the explanations why so many rock paintings in Finland and carvings in Norway are located at the water's edge is because the art has been one way of recording visions and interactions with spirit beings, especially animals who have resided in Säiva and Jabma-Aimo. The nature and content of zones and borders which divided the cosmos into different levels are depicted through rock paintings, carvings and drum symbols that emphasized that the vocation undertaken through journeys to the world of the ancestors and above the earth by the noaidi. Knowledge for example, of the abode of the departed has been one of the main features which are found painted within the cosmological structures of Sámi worldviews in different sources of art. Furthermore, within written sources pertaining to the history of Lapland, early material which presents evidence of the use of the decorated drum by a Sámi noaidi is recorded in one of the

oldest document that describes a shamanistic séance, [and is from] the eleventh-century Historia Norvegiae; [where] the markings on the drum are mentioned as containing only figures representing whales, a harnessed reindeer, skies and a boat with oars. They have been interpreted as representing the means of transport for the shaman on his journeys or his spiritual assistants (whales). (Pulkkinen \& Kulonen \& SeurujärviKari 2005: 73)

Illustrating no doubt that drums have been an integral part of the culture for a long time.

\section{PAINTED DRUMS AND OUT-OF-BODY TRAVEL}

The magical drum as a sacred vessel was used for different reasons, including the practical use for divination where the noaidi sought the will of the spirits in matters related to fishing, hunting and problem solving. In addition, another common use was for ecstatic entrancement associated with healing purposes where the use of the drum was employed to induce a state of ecstasy via the application of rhythmic chanting and singing in the form of joiking. Joiking creates 
tones which produce various sounds, and has been a customary practice used by noaidi's to help shift from mundane consciousness into trance states. When shamanizing the noaidi with the assistance of helping spirits undertakes soul journeys into the world of the dead below the water or inside the earth in order to return lost or stolen soul parts to a sick or injured person. Journeys were also made upwards into or realm of the gods/spirits, which were of a celestial nature, for example, who controlled the weather and helped with successful hunting. The drum as a sacred vessel was also used during sacrificial activities where sacred boulders and carved wooden idol type posts called Sieidi which quite often resembled human or animal forms were approached. Offerings of tobacco, meat, fat and fish were typically made to the residing spirit as a way of invoking help and advice with community, family and individual affairs with life and death situations as well as fortune-telling and prophesying. Sacrifice was performed through appeasing the spirit residing in the boulder or wooden idol which then offered power in return.

On many drums, symbols are placed within a type of network which included a host of features such as the heavens, northern Lights and Milky Way, where the Sámi deities of the upper world resided. In the middle world - physical reality which was concerned with hunting and fishing activities, there were spirits who took up residence in sacred hills, mountains and boulders across the landscape. Below the earth in Jabma-Aimo was where Rota the god of illness and death resided and who the noaidi made extensive sacrifices to as a way of alleviating sickness and disease. The co-existence of all of these elements was both the essence and portrait of a definitive archaic worldview characterized by sacrificial activities, reindeer herding, hunting and fishing, which spans thousands of years.

Variations in the cosmological structures of the universe which could differ in accordance with the noaidi's experience and understanding of the rotational shifts throughout the cyclical year are also evident. As a sacred instrument, the drum for the Sámi had as much significance and value as a bible or Holy book might have, and in some instances, such was the reverence for the vessel, sacrifices were offered to the spirits who had taken up residence inside and were associated with it. Typically, the noaidi made contact with the spirits through the drum when seeking for example, the desired power for successful hunting, healing and divination.

Decoration of the drum was vitally important too. The pictorial content on each of the drum heads which were made of reindeer hide were painted with red dye from alder tree bark that had been boiled or chewed before usage. "The red colour of alder bark, symbolizing blood [is a substance utilized as a medium that acted as] a key to control the elements" (Mulk \& Bayliss-Smith 2007: 60). 
The red colour of alder dye also had religious significance for hunting, and was seen through the deity who is called:

[...] Leaibealmmái - the alder tree man [who] was the God of Hunting. The alder tree was regarded as a sacred tree. With dyes made from the bark, the people painted figures on the goavddis - drum. Leaibealmmái had control over the wild animals of the woods. (Solbakk 2007: 34-35)

\section{USE OF THE DRUM AND PREVIOUS RESEARCH INTO SÁMI SHAMANISM AND THE NOAIDI DRUM}

Previous scholarly research into Sámi shamanism has described in a number of ways the drum might be used by the Sámi noaidi for healing, divination and making out-of-body journeys to other worlds. From these observations, the drum has been labeled as a 'Cognitive Map' in literature, and the pictures drawn on the drum head formed the mental landscape of the noaidi. For example, Pentikäinen (1998: 39), informs us that:

the drum is a key to the cosmology of the Sámis. The shaman had an intimate relationship with his own drum which was often made by him. The figures of the drum were a kind of cognitive map for the trip of the shaman's ego-soul between the three levels of the universe. [...] The cyclic world-outlook of shamanism became manifest in the oval shape and the heliocentric figures on the drum.

According to Keski-Santi et al (2003: 120-122):

[...] the definition of a map is shaped by cultural contexts and that within different cultures maps can vary in both appearance and use. For the Sámi, the drum was metaphorically speaking, the shaman's sleigh: the drum itself, the drumming and decoration of the drum skin together functioned as a map. This map was created by an individual shaman's spiritual journeys, which he or she had made for the benefit of, and on behalf of, the community that he or she had a calling to serve.

By contrast, Swedish Sámi scholar Louise Bäckman also informs us that:

all noaidi did not have similar experiences during contact with the gods, or 'other reality', but all noaidi were acting within a culture that supplied each with the same frames of reference. Noaidi were brought up with the 
same religious traditions, and interpreted experiences in a traditional way, but in accordance with personal experience. (Bäckman 2004: 30)

One important source which has presented a deeper insight into the role and function of the noaidi in Sámi society is provided by Sámi historian Veli-Pekka Lehtola in his book: “The Sámi People: Traditions in Transition” (2002). Lehtola provides a description of Sámi shamanism from inside the culture which has historic ties to the past and present:

In the old culture, human relationships with the two realms of reality, the physical world ("this side") and the spiritual world ("the other side") were bridged by the activities of special men and women - noaidi. Just as the world was divided into the seen and unseen, the tangible and the intangible, so human beings were composed of two parts: the body souls and the free souls. In a non-active state - in dream, trance or coma - a free soul may leave the body and take on another form outside of the person. The noaidi had the skill to reach this state at will. It is described in different ways. The noaidi in a trance leaves the body and moves as a spirit of breath or wind. They have the ability to change into a wild reindeer or hide under the reindeer's neck or hoof; they can fly over tree tops or travel under the ground; they may swim in the shape of a fish; and the Sea Sámi recount that they may even move mountains. The traditional shamanism was an integral and essential part of the hunting culture. Shamanic activities were related to crisis situations in a village or family; the noaidi attempted to find a remedy. The greatest crises for this people dependent on nature were illnesses and problems concerning obtaining a livelihood. Illness is a disturbance of the balance between the two souls and between the two realms of reality. The noaidi, in spirit form, leaves and goes to the "other side" to restore harmony. (Lehtola 2002: 28)

Further research from scholars within all major academic disciplines across the Nordic countries from the 1980s to the present time has made a significant contribution towards understanding the different uses and activities associated with the magical drum. For further examples see the following: Pentikäinen (1998), Laestadius (2002), Sommarström (1991), Ahlbäck and Bergman (1991), Hultkrantz and Bäckman (1978; 1985), Holmberg (1964) and Manker (1938; 1950). During the course of the 1980s in the Nordic countries, interest into the "remaining 71 drums" (Itkonen 1943-44: 68) which survived the colonialism era and were collected from the Finnish, Swedish and Norwegian Lapland when the reindeer and fishing culture of the seventeenth and eighteenth centuries appeared to have reached its peak. Within this period, the remaining drums 
and their decorative content, which are currently preserved in various museums throughout Europe, were extensively analyzed within the sources noted above.

Perhaps one of the foremost and comprehensive literary sources that has emerged in relation to the study of Sámi noaidi drums has two volumes and contains extensive photographic records of all the surviving drums, and was published in German by Ernst Manker (1938) and titled: Die lappische Zaubertrommel. Eine ethnologische Monographie. 1, Die Trommel als Denkmal materieller Kultur, volume 1. A second volume (1950): Die lappische Zaubertrommel: eine ethnologische Monographie. 2, Die Trommel als Urkunde geistigen Lebens, analyses the many symbols, figures and structures painted on the drum heads. Both of Manker's editions have been used widely and extensively within all academic research fields as source material. Because a number of the sources above have been formulated by persons from outside Sámi culture, methodological problems exist in research into how the use of the drums were recorded during the colonialism period. The reason being that interpretation of figues which figured prominently in the so called Witch hysteria, originate from accounts provided by preists, and are therefore, to be treated with a certain amount of caution.

\section{AIMS OF THE RESEARCH AND METHODS USED}

The aims of the research is to bridge one of the current gaps which exist in relation to Sámi culture throughout the Nordic countries today, and concerns a lack of data discussing the production of new types of shaman drums which are emerging, as Christian influence begins to lose its grip in Lapland. There is a wealth of knowledge and information published about the old drums from the seventeenth and eighteenth centuries, but we have no data of any kind about modern drums made by Sámi persons, especially those that are engaged in the practice of shamanism. Furthermore, previous enquiry throughout the past thirty years for example, has sought to study the Sámi noaidi mainly as a religious specialist from within a historical context, and not as an artist or handicraft person. Therefore, the proposed aims in the paper are concerned with examining the influence the painted symbolism from the old drums from the seventeenth and eighteenth centuries have had on the production of six modern drums made by Elle-Maaret Helander who lives in Finnish Lapland, and Ovlla Gaup who is a Sámi from Norwegian Lapland. Both drum makers are artists. The material presented herein has been collected through fieldwork and collaboration with the two Sámi persons as a result of interviews conducted between 2011 and 2013 in Finnish and Norwegian Lapland which is introduced 
below. To help set the scene and in order to describe the role and function of the noaidi in a historical context, an explanation of Sámi shamanism and use of the drum has been presented above as a foundation for the task ahead. What is also required to support the above is photographic evidence of older drums and their different typologies. The old drums from the reindeer culture of the seventeenth and eighteenth centuries played a vital role in the construction and continuity of culture and identity. When gathered together, rock carvings, rock paintings and drum symbolism illustrate how religious practices recorded as oral heritage appears to go back thousands of years. Reasons for making use of the historic material within the paper are to show the level of influence as well as contrasts noaidi symbolism has in relation to the reproduction of those symbols painted on new types of shaman drums and decorative artwork by the two interviewees.

The formula of analyzing and describing the usage of the noaidi drums from earlier sources, and presenting the material as photographic evidence helps strengthen the analysis because it covers the wide range of uses of the instrument and provides the reader with knowledge of its value and importance as a religious tool. A comparative presentation of material supports the enquiry which draws comprehensive links and parallels between the influences the drums of the old reindeer culture has with regard to the ways they were built-constructed, and the application of shamanistic art, by contrast to the production of new drums in modern society. Overall, the background-historical information is essential for creating the basis for the new analysis. Moreover, both the approach used and methods employed help to show how continuity of Sámi culture takes place, and present a number of the factors and techniques involved in drum making amongst the interviewees that have both similarities and differences. The evidence presented in this way, is done so as an attempt to capture the motivation behind the art. A suitable model for the research warrant's a descriptive approach using a comparative methodology that demonstrates how the past influences the present with regard to the reproduction of drums and artistic symbols, and subsequently helps to determine the outcome of the research question. The content of the chapters are presented in this order because they strengthen and support the aims of the study.

In addition to making descriptive comparisons between past and present in relation to noaidi drums and their symbols, it is beneficial beforehand to have some insight into the Sámi handicraft tradition in Lapland which is called Duodji. Duodji is a term used to describe authentic Sámi handicrafts that are handmade by Sámi persons, within a large number of artistic designs and various handicraft productions that have been decorated with intricate patterns and forms produced from within the culture. Duodji items are decorated with 
different symbols and patterns that transmit culture, and are recognized as sources of traditional knowledge, brought into form through products such as knives, bowls, clothing, leather and bone items, made using natural materials and dyes, many of which are decorated with intrinsic patterns which express "[...] an inner human creative process" (Solbakk 2007: 64). It is amongst the traditional practices of making Duodji handicrafts and creating art that one is able to encounter the noaidi drums in both a historical and modern context. Certain drums are used in a shamanistic way, whilst others perform a decorative or cultural function. Drums are one of the central manifestations of cultural heritage on which the noaidi's painted patterns and designs as intricate symbolism are found that reflect the worldview of many generations, and their relationship to the natural world.

\section{MATERIAL OF THE STUDY}

The overall content of the proposed paper has three main sections to it. The first section (above) contains literature sources that present an overview of material of the Sámi noaidi drums and drum symbolism from between the seventeenth and eighteenth centuries, from the Lapland areas in Finland and Norway. Motivation for using literature studies in this way is to help introduce the noaidi's role as an artist and bearer of both tradition and culture, from a perspective which creates a foundation for the contemporary analysis of drums made by Sámi interviewees which is presented in the last section. To help support the proposed analysis, it is important to become acquainted with material which gives a brief introduction to the persecutions of the noaidi in Lapland as a way of highlighting the painful historical legacy passed on from generation to generation. The reason for including this dimension of cultural history is done so as a way of providing a certain level of understanding towards the historical landscape being navigated through which is where the origins of the research into Lapland by priests comes from. The treatment of issues concerning persecution is warranted in this case from the point of view of awareness, for persons from outside of Lapland culture. The emphasis being the impact of colonialism and Christianity with regard to the noaidi drums usage and persecutions of noaidi's in a long and brutal campaign throughout Lapland by the church. From literature produced from within the colonialism period that extends from the seventeenth century until very recently, evidence shows that the banning of the use of Sámi language which has been portrayed through two fundamental elements, namely, art and culture, had a serious impact on both the identity and self-esteem of the culture. These issues have to be taken into consideration 
because they continue to influence Sámi attitudes, thinking, culture, art and religion, and from more recent observations, the way new drums are produced and the pictorial narratives which accompany them.

As a way of conveying the chapter outlining the persecutions, included is a photograph of a painting by "Esa Marlisto [who] is Finnish speaking [artist] [...] born in Tampere, Finland. [Marlisto] has [also] lived in Götebord in Sweden" (Marlisto 2013: 1). [Marlisto's] painting has "no specific historical document behind it, but [from the author's point of view the art] presents a general portrait of Sámi history" (Marlisto 2013: 1). The reason the picture has been chosen as a part of the analysis is because "this particular portrait [of a dead noaidi] exhibits the humiliation of [being stripped naked and] being tied to a religious icon, [in the form of a wooden Sieidi]" (Marlisto 2013: 1) and left to die. Moreover, the portrait helps capture the atmosphere as to why Sámi noaidi's and some handicraft persons are reluctant to give interviews and disclose information to persons from outside their culture, regarding drum making and religious practices.

Information from Marlisto's bio stated that the painter's exhibition titled 'Saami symbolit' (Saami symbols) exhibited in 2013 at the City Library in Rovaniemi, which is the capital city in Finnish Lapland, was a collection of works with this type of content was inspired from the artist's visits to:

Northern Canada in 1971, where contact was made with indigenous people of the new continent. The second contact with indigenous people was in Greenland in 1976 where Marlisto met Eskimo persons. In 1989 in Sweden Esa learned about the Sámi, who he sees as the indigenous people in Finland who are 'our' indigenous people, and remembered what he had seen in Indian and Eskimo societies previously. As a result, Esa began to study Indians' and Eskimos' and recognized the similarities between Sámi histories. He started to call the Sámi 'Our Indians' and this is where he got the motivation for the theme. (Marlisto 2013: 1)

One further important source of information included herein that follows on from the chapter on persecution, is the chapter titled: 'Old Sámi drums as sources of traditional knowledge for Sámi society today'. This section, like the previous one, also has associations with persecution, and within the content is a photograph of an old drum from Finnmark, Norway which belonged to Sámi noaidi Anders Poulson. Poulson was tried for witchcraft in a Norwegian court in "1691" (Hagan 2005: 309). The reason for choosing the drum is because according to Norwegian scholar Hagan, and by contrast to the information about the remaining drums which survived the Lapland purges, this particular drum “[...] has been preserved, and it is one of the few drums containing symbols and fig- 
ures that have actually been described by the drum's owner" (Hagan 2005: 309). The description of the use of the drum in this example has been recorded and is presented in the paper below. Hagan also informs us that whilst Poulson was in custody awaiting a decision concerning a previous ruling against him where he had "[...] been found guilty of evil sorcery" the old shaman was murdered while sleeping in a hut the day the following on the court ruling (Hagan 2005: 312). Additional information by Hagan states that after the shaman's death:

Poulsen's well-used magic drum ended up in Copenhagen, in 1694. Today we can find the several centuries-old magic drum where it naturally belongs: in the Karasjok Sámi Collections (Sámid Vuorká Dávvirat), Finnmark. The drum was consigned to the Sámi Collection, in 1979, by the National Museum of Copenhagen. (Hagan 2005: 309)

The grounds for placing special emphasis on Anders Poulson's case and the preservation of his drum, is to illustrate the influence it has played through the reproduction of a replica of Poulson's drum. The replica was made by Ovlla Gaup, the Sámi handicraft interviewee from Kautokeino, Norway, and is presented within the context of the study as well. Although the information provided by the drum maker is short, the prototype made by Gaup is a good example of how the historical events surrounding the original drum has influenced the drum maker, and as a result, the instrument is presented as an art form which represents "[...] the maintenance of Sámi culture and identity" (Gaski 1997: 1). In other words, how traditional knowledge survives and is carried forward. As a way of gaining background information about the drums creation and story behind it, telephone interviews with Ovlla Gaup were conducted in 2011 and 2013.

To follow the presentation surrounding the explanation by Poulson and the description of his drum, the chapter further includes photographic material of two more drums, one from Finnish Lapland and the second from Norwegian Lapland. These photographs are examples taken from amongst the "remaining 71 drums" (Itkonen 1943-44: 68) that have survived the Lapland purges of the seventeenth and eighteenth centuries. Documentation of each drum is detailed in Ernst Manker's (1938) edition. Currently, all the surviving drums collected from the Sámi, are preserved in museums in Italy, Sweden, Germany, Britain, Denmark, Norway and France. The photographs of the historical material help to characterize the diverse illustrations of individual spirits and deities; human figures and animals that formed the mythical worldview. Illustrations of figures which are both individual as well as in groups are placed within cosmological structures on the drum heads painted by the noaidi; the structures on each drum have been created from the noaidi's knowledge and experiences. Included too in this section, is information about the collection of materials by the noaidi 
used to construct drums with, which was translated from German to English by Martina Schäfer. The drum presented from the Finnish side of Lapland is one of the only two known remaining Sámi noaidi drums that have originated from the former Kemi Lappmark area in Finland. The instrument which is seen presented herein exhibits both frontal and rear views. The reason for presenting both sides of the drum is to illustrate the typology of the instrument which is the frame design; considered by Manker (1938) as a type associated with the Finnish Kemi Sámi. The frame drum consists of a piece of wood bent into an oval shaped which had a handle in the center in the form of a cross piece. The Kemi drum is the segmental type which means through the noaidi's artwork and cosmological picture, the landscape is divided into three segments on the drum head that consists of upper, middle and lower world structures and figures.

Figure four is an additional illustration of a Sámi noaidi from the seventeenth century who is beating his drum prior to falling into a trance. The image is included because it shows the divination ring on the drum head which is being struck with a reindeer bone hammer before the noaidi falls into an unconscious trance. Bronze or copper rings acted as a pointer or guide during divination which helped determine the will of the spirits. A bone hammer used for beating the drum with was typically made from reindeer horn which was $\mathrm{Y}$ shaped in its design. Two more photographs are included in the historical section presenting, both front and rear views of the Sámi drum from Norwegian Lapland which is decorated with spirits and deities who have extensively influenced the artistic productions of Sámi persons. The Norwegian drum is a bowl type drum, and is made from a burrell from a birch tree. As is evident, the cosmological structure on the drum has five levels to it. The instrument is a Sun-centered drum meaning the painted landscape is created around the image of the solar symbol thus highlighting how important the reverence for the sun in Arctic cultures, and therefore, how the world picture is structured around it. The cosmological structure of the bowl drums exhibits the variations to different levels, for example, upper, middle and lower worlds but also realms just above and below the earth.

To provide the reader with some idea of the geographic locations of the main areas where the drums in the historical section of the paper have originated from; enclosed is an old map of Lapland which was divided up into different regions by the Swedish state during the colonialism period. This map (see Figure 1) was provided by Risto Pulkkinen who is a Docent at The University of Helsinki.

The third section of the paper examines the transition from noaidi drums to modern 'shaman' drums, and in this case the research material is presented through five drums which have been made by Sámi drum maker, artist and 


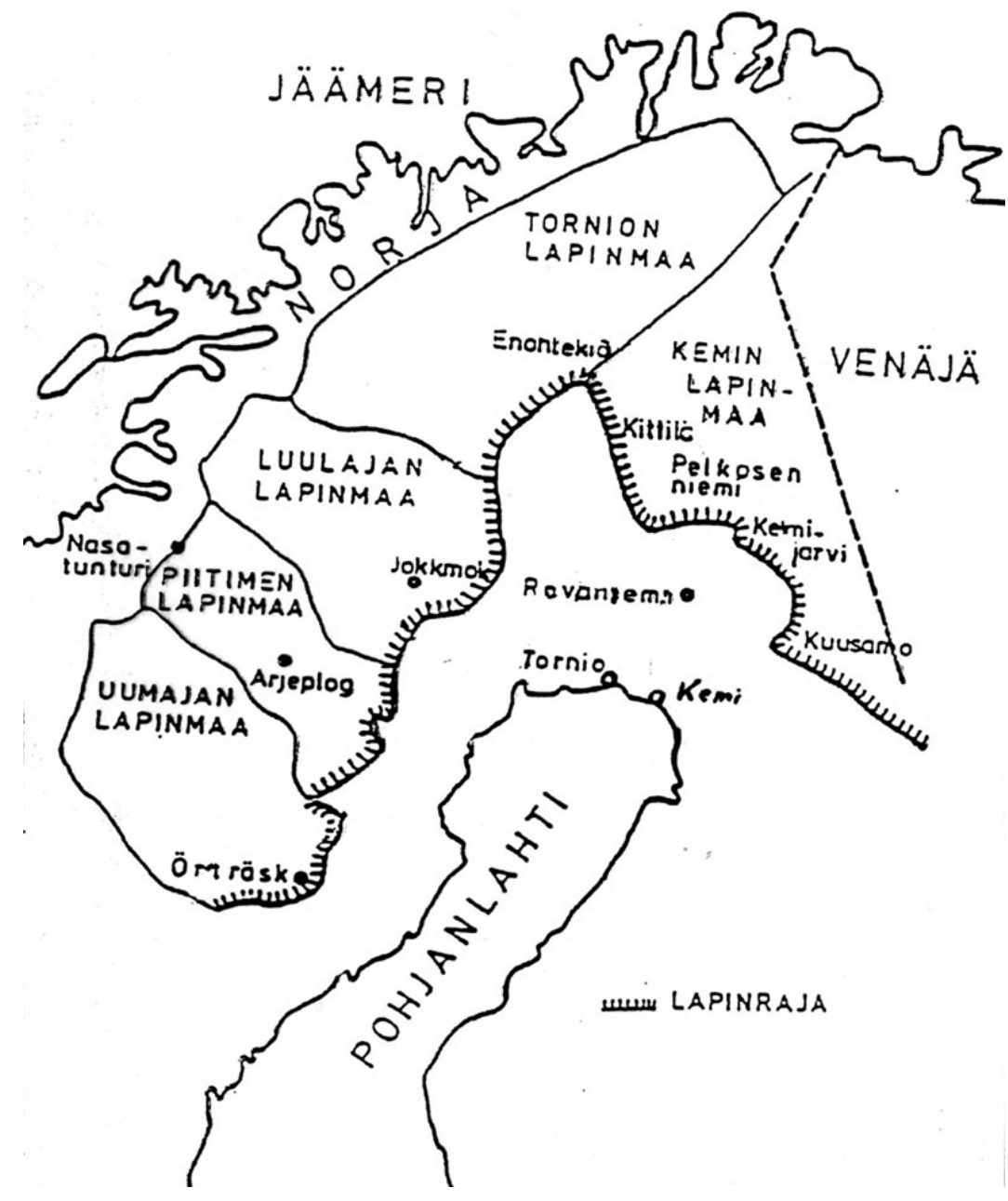

Figure 1. Photograph of an old map of the former Lapland provinces which were divided into different Lappmarks for taxation purposes. On the left side is the Kemi Lappmark area. Many noaidi drums were subsequently collected and destroyed from the Umea, Pite, Lulea areas of Sweden as well as the Finnmark municipality in northern Norway. Drums were also collected and destroyed from the Tornio and Kemi areas of Finland which are presented on the map. 
visionary, Elli-Maaret-Helander. Elli Maaret is a Sámi woman, “originally from Utsjoki municipality on the Tenojoki river, near Karigasniemi, [the area] is called Rovisuvanto" (Helander 2011: 1). The area is geographically located in Finnish Lapland within the Sámi homeland. Helander who currently lives in Pyhätunturi Pyhäjärvi in Eastern Lapland comes from an agricultural family where there was no reindeer or fishing activities. The background information and inspiration for Helander's drum making began after undertaking a basic course in core shamanism in " 1997 with Finnish Shaman Reino Knappila from Helsinki” (Helander 2011: 13). Additional learning was then undertaken through a drum building course in Finnish Lapland in "Inari at SAKK, an educational center for Sámi people" (Helander 2011: 1). Further influences on her path as a drum maker have come from Helander's two daughters who are musicians. As musicians, the girls have, for a long time, been performing "traditional old songs with joiking music" (Helander 2011: 2), in public performances and at concerts. Joiking is the ancient form of singing which is native to Sámi culture and is a strong feature of identity for both man and women.

Because the author does not speak Finnish or Sámi language, one of the ways to try and overcome potential language difficulties prior to the interview with Elli-Maaret, was to employ the services of Jenni Laitinen, a Finnish woman who speaks English, currently living in Rovaniemi, Finland. Jenni offered to translate the interview with Elli-Maaret Helander, who also speaks Finnish. Having to employ a translator brought to mind how perhaps one of the reasons why so little is known about the practice of shamanism amongst the Sámi at the present time. The reason being is adherence to traditional ways, customs and taboos, usually, the Sámi do not speak about their religion to persons from outside the culture, especially with regard to shamanism and noaidi drums. The customs and taboos are one reason, but perhaps the underlying factors are because of what happened to Sámi religion during the Christianization of the culture between the seventeenth and eighteenth centuries and the subsequent persecution which followed, by the priest and missionaries who were from outside of the culture. What this means is it is important to explain that as a result of the historical events which have taken place in Lapland, this type of investigation deals with culturally sensitive material in relation to using pictures of the old drums. Another key point to mention is many Sámi persons, especially the elders, do not speak English; they speak either in their native language or Finnish, Swedish and Norwegian.

The essence of the interview with Elle-Maaret Helander was to try and establish how the old drums influence the present, and what the motivation behind the artwork was and where the inspiration for the designs comes from. Material provided through the interview has produced a rare insight into one of 
the most controversial topics within Sámi history in relation to ritual art. As a result, important and notable contrasts were made evident during the interview that emphasized a shift in Sámi culture and traditional handicraft production with regard to drum making activities, which had much value for this new type of research. By comparison to the drums that survived the Christian purges of the seventeenth and eighteenth centuries, these as far as is known, were all owned by male noaidi's, indicating the role which has been a part of the tradition from earlier times. However, the content of Helander's drums although obviously somewhat different from those of the hunting culture, do still bear strong resemblance to ancestral drums with regard to portraits of animals and spirits that are native to Sámi culture, cosmology and religion. Illustrations of figures painted on the drum heads by the drum maker are still associated with rituals, myths and stories found in Sámi culture and also relate to the role of the noaidi in Sámi society around which a substantial amount of Sámi art is produced in relation to identity. Elli-Maaret holds regular workshops on drum making throughout Finland and does not produce or sell drums for souvenir shops because "[...] she does not want to commercialize her work" (Helander 2011: 8). After each drum is constructed it is painted with motifs that are the artist's designs.

During the interview at her home, permission was given to photograph 4 drums that had been had made previously, and to document the nature of the stories behind the painted-decorative content on each of the drum heads, and rear views of two of the drums. Special attention was paid during the collection of data as to how the new illustrations reflected elements of the old culture. The purpose of observation was to try and capture the way symbols which are part of the intangible cultural heritage of the Sámi were adapted to modern culture and society through the artists work. A photograph of a fifth drum made by the Elle-Maaret that was on display at the Sámi Siida museum in Inari, Finnish Lapland is also included below, and was photographed in 2012. In addition to the four drums photographed at Elle-Maaret's home, the drum from the Siida Museum also has value for the study because part of the content of the art shows many of the Sámi spirits and deities who are recognizable on drums from the seventeenth and eighteenth centuries presented in the paper. Thus indicating how both of these phenomenon's' and their representations continue to play a role in Sámi society as a way of transmitting and preserving culture, identity and sacred narrative.

The second interview in the research was with Aslak Paltto, a Sámi journalist from a reindeer herding family from Lemmonjoki, in Finnish Lapland who is a drum maker. The interview with Aslak was conducted in English at The Siida Museum in Inari during the Skábmagovat Indigenous Peoples Film 
Festival in February 2011. The purpose of interviewing Aslak was to ask the participant about his knowledge of Sámi shamanism and use of the drum in Finnish Lapland. Although none of the text from the interview with Aslak is presented in the paper, he agreed to provide two photographs of a reproduction of a bowl type drum which was made by Ovlla Gaup from Kautokeino that is mentioned above, as belonging to noaidi Anders Poulson.

Later In 2011, in a telephone interview with Gaup, the following information was received.

In 2001 Gaup undertook a handicrafts course at a Sámi Duodji school in Jokkmolk, Sweden. The reason for choosing Polson's drum was because it is the only surviving northern Sámi drum, and Gaup is a northern Sámi. Through building the drum, there was a sense of reclaiming Sámi identity and Ovlla did not want the skill of drum making to disappear. (Gaup 2013: 1)

The photographs have much value for the research because and "the shape and design of the drum [despite it reflecting the same bowl typology] was a new model, Ovlla's own design" (Gaup 2013: 1).

\section{THE PERSECUTION OF SÁMI NOAIDI'S AND THE COMPLEX HISTORY OF LAPLAND}

One of the most investigated fields of enquiry in relation to noaidi drums and the practice of shamanism in Lapland concerns the conquest by the Lutheran Church, its missionary workers and priests during the colonial era throughout the seventeenth and eighteenth centuries. The authority of the church interpreted Sámi religion and religious practices to be evil and a serious threat to the political climate of the Swedish Kingdom of both which Finland and Norway at the time were a part of. The conquest by the state took place during the Church's drive to assimilate the Sámi who at the time were referred to as the 'Lapps' into mainstream society by hunting down noaidi's, putting many to death and confiscating and burning their drums in the hundreds. Such was the impact of the conversion and terrorism that the religio-cultural upheaval subsequently administered to the Sámi, in turn brought about a significant loss of traditional culture and identity in relation to traditional religious practices. Sámi historian Veli Pekka-Lehtola states that in Lapland up until the 18th century "the traditional shamanism was an integral and essential part of the hunting culture" (Lehtola 2002: 28). After this time the practice appears not to have vanished completely but gone underground and become secret. "The 


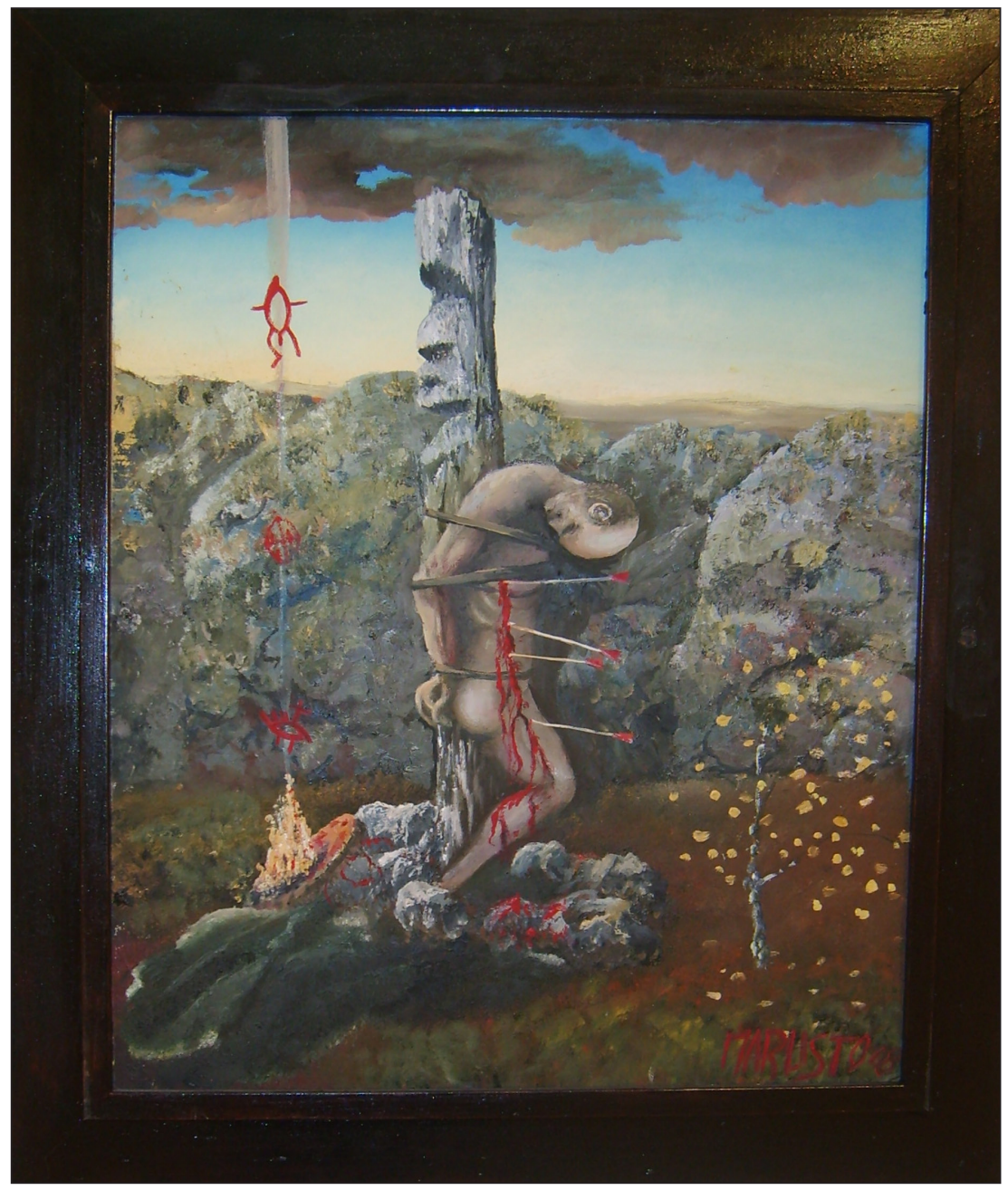

Figure 2. Above is a portrait from an exhibition at Rovaniemi City Library which shows a dead Sámi noaidi-shaman, shot by four arrows. The picture has been painted by Finnish artist Esa Marlisto, who has portrayed the persecution of the Sámi people through his art. The title of the picture is: 'Shamaanin Marttyyrikuolema: The Martyrs death of a Shaman'. The text describes the artist's sentiments:

When the Reformation [missionaries and priests] came to Lapland they looked down on the Sámi people and thought they were lower. All the tools were taken away which were used for practicing Sámi religion. Also, the Sámi language and joiking, everything was wrong according to the outsiders. In my opinion, this was a pure execution. (Marlisto 2013: 1)

The content of the painting shows the noaidi stripped naked and tied to a wooden Sieidi which has anthropomorphic features to it, that has been constructed from a tree trunk to which sacrificial offerings and worship would have been made. The noaidi's drum is on fire behind him, and the painted images from the drum head as well as the spirit from the drum are travelling towards the sky, thus indicating how the symbols were alive and with power. 
noaidi's most important instrument was the noaidi drum [which became one of the main symbols of resistance against the church]. It was a tool to enter the ecstatic state as well as a "map" the noaidi used for orientation in the other realm" (Lehtola 2002: 29).

From this period Sámi religion and related practices were outlawed by the Swedish Church and state to such an extent that many people rejected and denied their own culture and identity; the traces of which are still apparent in Lapland today.

During the course of the Witch persecutions throughout Lapland

many chose to hide the drum since they then could continue to use it. To mark their ethnicity openly with the drum was not a realistic choice since the superior force was too great. Threats and punishments were used to force the Saami to abandon their religion and take away the drums. (Berglund 2005: 137)

Although there is no written evidence regarding the types of torture and punishment administered to noaidi's who refused to hand over their drums, one account from Norway states the following:

[...] Carl von Linne, one of the greatest enquirers into the laws of nature, of the Enlightenment. Linné also obtained a drum, with which he was depicted on several occasions. In 1732 he travelled to Lapland and then visited the Norwegian coast, for example Tørrfjorden north of Bødo. Linne (1732 [1965]: 103) wrote that he had heard that drums were taken from the 'Laps'. If 'the Lap' refused to hand over the drums they opened a vein in his arm. Then 'the Lap' fainted, begged for his life and gave up the drum. (Berglund 2005: 140)

In relation to the above, in an interview with a reindeer herder called Lauri Ukkola from Vuotso village which is one of the Sámi areas close the municipality of Sodankyla in Finnish Lapland in 2011, the informant described how he remembered that as a boy after the Second World War had ended, there were drums in some of the houses in Vuotso village, and "when he was in school, the priests collected the drums from attics and houses and burned them. They were the Sodankyla priest's" (Ukkola 2011: 4). This account shows how the mentality of the priests from the seventeenth and eighteenth centuries was still persistent some three hundred years later, and it may also be added can still be encountered in the Sámi homelands in Finland at the present time in relation to the denial of Sámi culture and outlawing of their native religion and practices. 


\section{OLD SÁMI DRUMS AS SOURCES OF TRADITIONAL KNOWLEDGE FOR SÁMI SOCIETY TODAY}

Accounts of witchcraft from the Finnmark province of Norwegian Lapland which have been published through the scholarly work of Norwegian scholar Rune Hagen's (2005) 'Traces of Shamanism in the Witch Trials of Norway: The 1692 trial of the Sámi Shaman Anders Poulsen', who describes for example both light and dark aspects of Sámi sorcery, the darker being referred to as "The black arts of Sámi shamanism" (Hagen 2005: 314), and that the Sámi, like sorcerers in most cultures did use black arts against their enemies.

Another account from a slightly later time describing the usage of a Sami noaidi drum and its different functions was given during the period from the Witch hysteria and executions in Europe at the trial of Sami noaidi Anders Poulsen in Finnmark, northern Norway in who was an elderly man charged under the Witchcraft act.

[...] Poulsen's description of what kind of magic could be produced by the magic drums is of particular interest. He identified the following six areas of use during his February 1692 interrogation:

If someone had cast a spell upon another, Poulsen - by the aid of his gods - could remove the spell and reverse its power. He could thus send the spell back to whoever had first cast it [...].

He could track down thieves, and retrieve stolen property by consulting drum. He would play until God punished the thief, and the thief would then dry up like a fig [...].

By the power of prayer and music he could cause good luck to fall upon his people's reindeer: insuring that the reindeer would not be killed by wolves.

He would also play upon his drum to help relieve the pains of childbirth for laboring women. The drum's Maria images (Section C, no 1 and 2 ) were known to alleviate suffering.

In a similar manner, he could discover how his family was doing at home while he was far away from them. He could know the situation other people were in even though they might be several thousand miles away [...].

In addition, Poulsen said that he heard voices when he lifted the drum above his head. It was as though two people were talking to each other [...]. ${ }^{1}$ (Hagen 2005: 317) 
To provide some understanding and insight into the process of divination below is a description outlining the procedure by the noaidi, prior to falling into trace and receiving answers and guidance to questions.

When the noaidi was going to use the drum, he/she placed a triangular object, "a $<<$ pointer $>>$ " made of antler, on the drum skin. The $<<$ pointer $>>$-called vuorbi or bajá-<<Baya $>>$ further south, could also be a small copper ring, which was called veaki-"Weiko" (which means copper). He or she would then hit on the skin with a mallet made of antler called bállin - "Ballem", "Palm". The vuorbi (which today means "lot" or "destiny") moved about on the drum skin and touched upon the different figures that were drawn there. The noaidi interpreted the will of the gods based on the figures the ring touched upon, and where it finally stopped. (Solbakk 2007: 30)

Typically, the Sámi noaidi drums are made from pine, spruce and birch burrell'swood, for the bowl types, as well as strips of wood which were cut from the trees for the frame type. Ernst Manker states that during the search for timber to build a drum with, it was important the tree was in many ways set apart from other ones, in its shape and form, and in particular the way it had grown, and "it was better if the tree had been hit by lightning" (Manker 1938: 191), because via this outcome the wood was seen to obtain special powers.

Collecting the necessary materials for constructing a drum had both practical as well as ritual significance which in Manker's inventory of the drums (1938) the religious aspect seems somewhat lacking because the practical reasons for drum building overshadows the ritual ones. Seemingly, during the search for

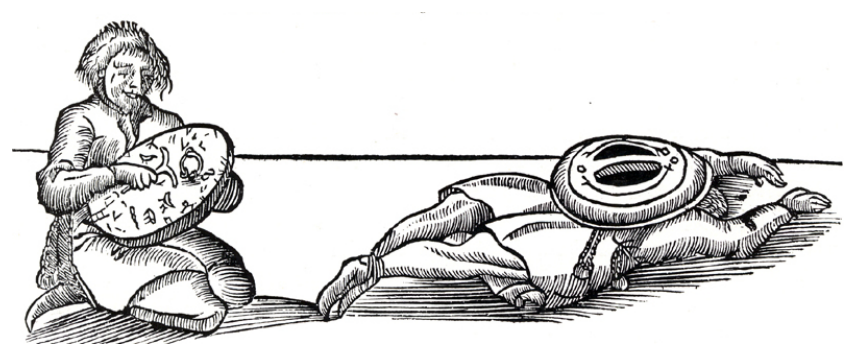

Figure 3. A noaidi beats his drum with a reindeer bone hammer, which has a bronze ring lying on the surface, he then falls into a trance. The illustration is taken from Schefferus's Lapponia, the original Latin edition 1673, and shows the drum to be of the bowl type. 


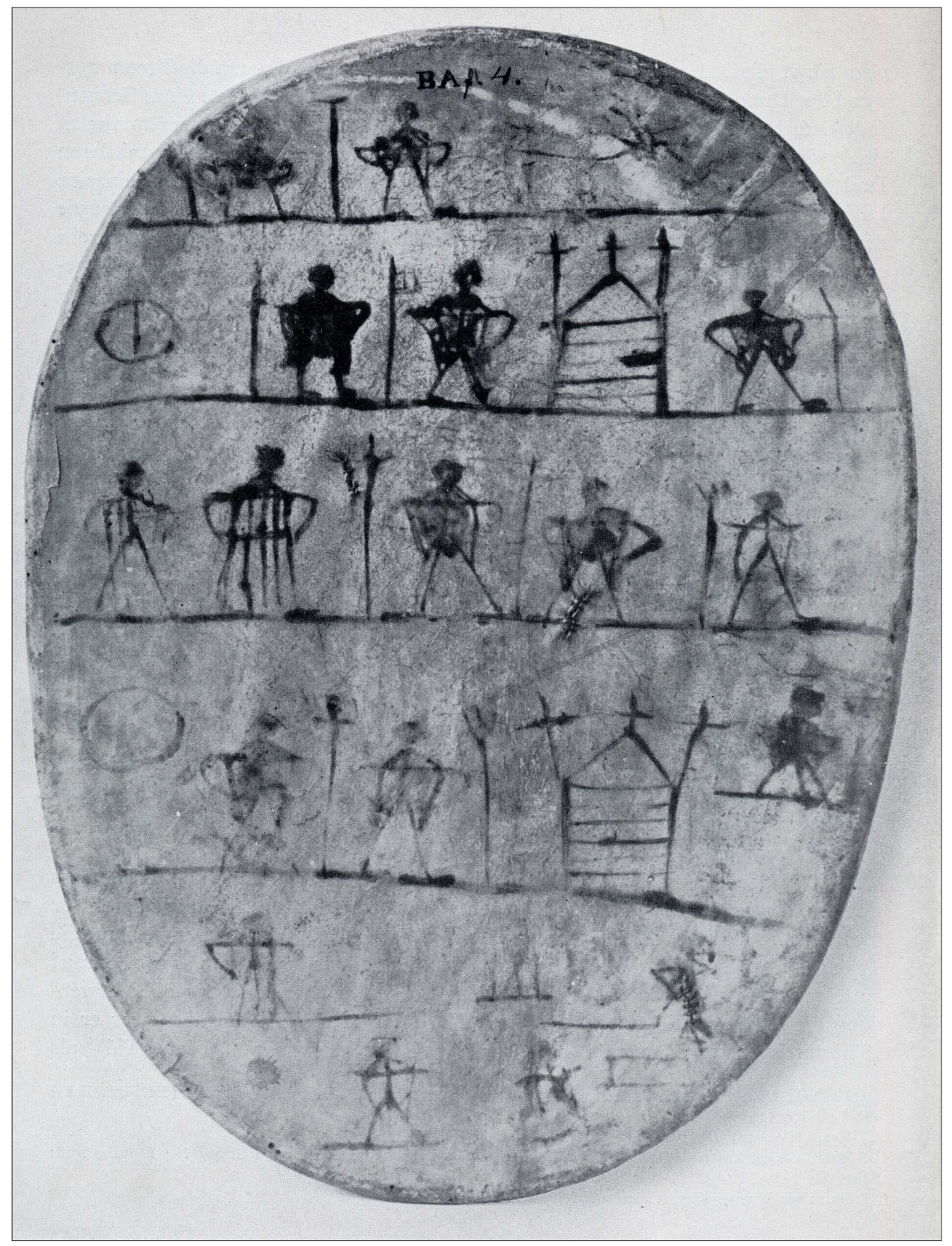

Figures $4 \boldsymbol{\&} \mathbf{4 a}$. This is the old black and white picture from Ernst Manker's book, showing both frontal and rear views of "drum no 71 from Finnmark. [The dimensions of the drum are] $43.8 x$ $32.8 \times 9.9 \mathrm{~cm}$ " (Manker 1938 drum no 71: p. 814; text \& pictures pp. 813-815). This drum which is of the bowl type originally belonged to the Sámi Noaidi Anders Poulson in at the beginning of the seventeenth century and is currently the property of Sámiid Vuorká-Dávvirat in Karasjok (Hagan 2005: 309). 
What Influence Do the Old Sámi Noaidi Drums from Lapland Play

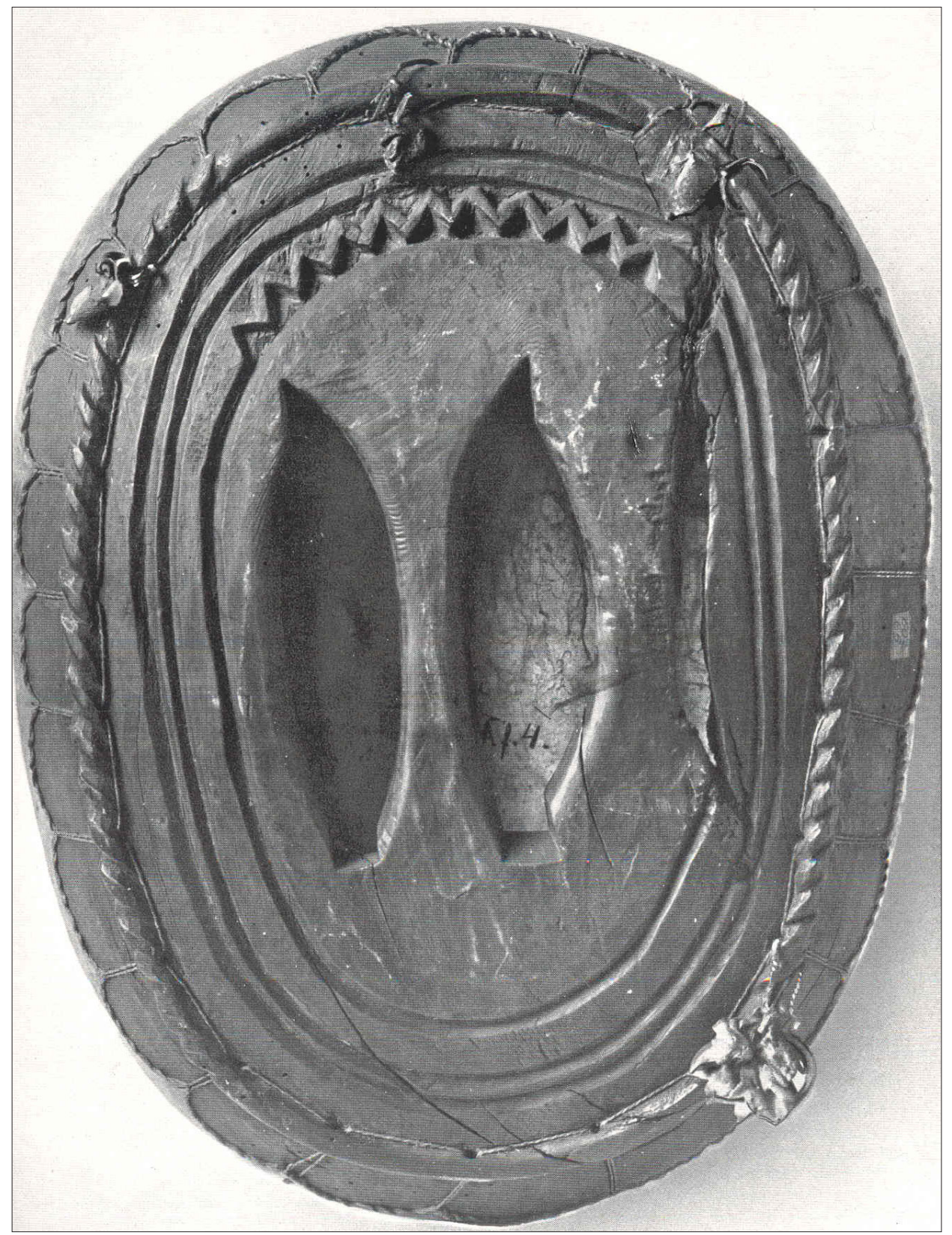

[...] the symbols on the drum skin are arranged into five rows or rooms. They symbolise different Saami gods but also have Christian symbols such as a church, The Holy Spirit and Saint Anna. [...] The drum is of the goadbes [bowl] type and is today in The Saami Collections in Karasjok. (Berglund 2005: 145)

On the top right side it is possible to make out the symbol of a reindeer. The content of the drum also shows the influence of Christianity from this time. 


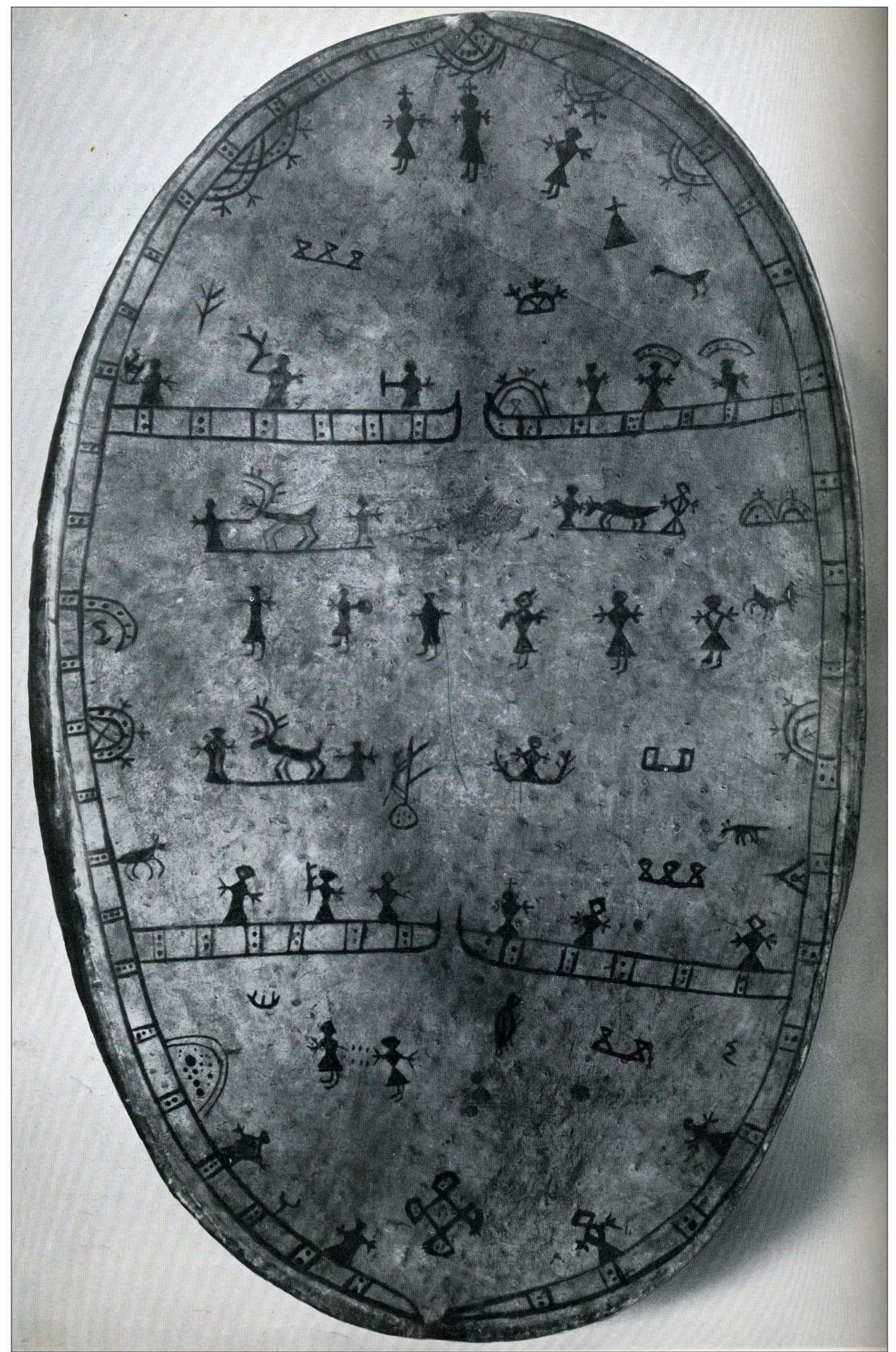




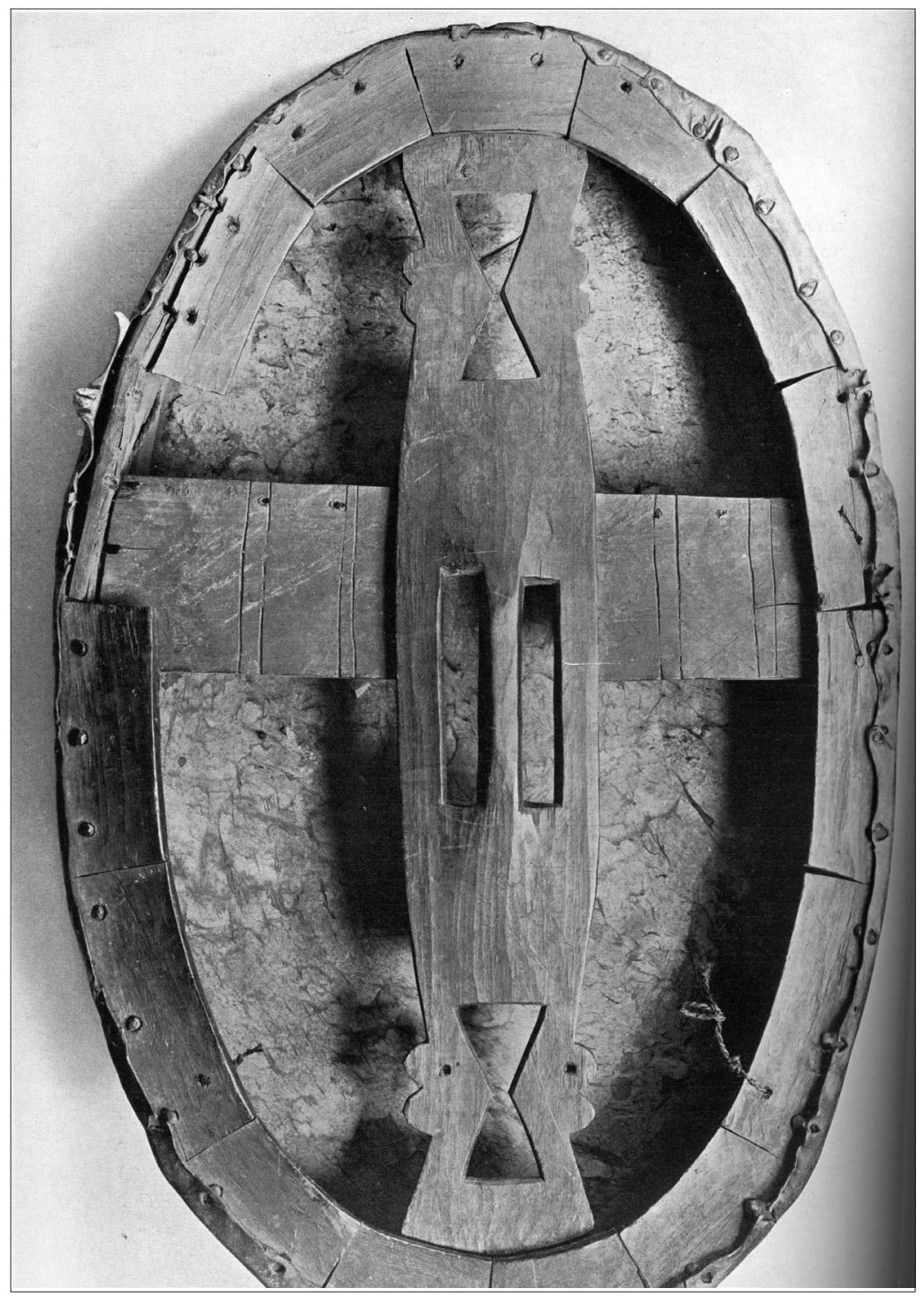

Figures $5 \mathbf{\&}$ 5a. The frontal and rear views of a large drum which is one of the two only surviving drums from the Kemi Lappmark area in Finnish Lapland, and is of the frame type. The instrument has its origins from the beginning of the seventeenth century and information about its history is described in detail by Johannes Schefferus in The History of Lapland (1674), first English edition. The instrument is currently displayed at The Siida Museum in Inari, Finnish Lapland, on long-term loan from The Museum of National Antiquities in Sweden. The size of the drum is recorded to be "85 x 53 x $11.5 \mathrm{~cm}$ " (Itkonen 1943-44: 69). Photograph by Manker 1938. The content of the drum head shows in the upper section of the drum, spirits in their respective positions. In the middle section are human figures with reindeer, and the lower section portrays spirits and structures from the world of the dead. 
relevant wood-materials, for construction a tree that was to some extent 'unusual' in its physicality had value for the Sámi according to Manker:

the type of wood to be used was due to the mechanical properties of the wood and not because of any religious observance. The wood was chosen for its strength and resonance, and it is possible the religious customs were built over this. Due to the influence of the sun, the wood received some rotational structure; one explanation for this was that the sun and gods chose-favored the tree. (Manker 1938: 190)

Because there were only "[...] 71 drums" (Itkonen 1943-44: 68), which survived the Christian purges of colonialism, many of the remaining drums examined in scholarly research have been divided into two classes.

Observations made by Archaeologist Inger Zachrisson in her analysis of the old noaidi drums, tells us they "[...] belong to two types. The oldest is considered to be the so-called 'frame (sieve) type', most of which have a frame consisting of a single strip of wood bent into a circle. According to Manker, in the Saami area this type of drum was gradually displaced, principally southwards, but also northwards. In its place came the so- called 'bowl type', which thus seems to have developed from the former, and is known only from Saami culture. [...] The 'bowl type' was more widely dispersed that the 'frame' one [...]” (Zachrisson 1991: 81).

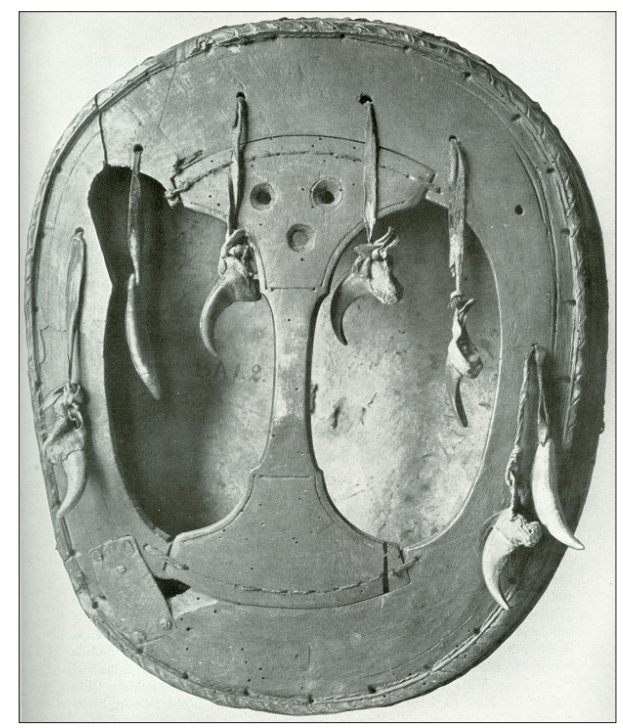

Figures 6 \& $6 \boldsymbol{a}$ present a black and grey photograph of front and rear views of a bowl drum. The image has been taken from Manker's 1938 edition. The instrument has an unknown origin, however, and according to the documentation by Manker, it may have originated from "Norland (Norway) and is dated as 1732, and currently the property of The National Museum of Ethnography, Copenhagen. The drum is labeled as no 52. [The dimensions of the drum in centimeters are] 42.7 $x 36.3$ x 9.9cm" (Manker 1938: 732-737). This type of drum which has a sun at its center was specific to areas in Swedish and Norwegian Lapland. The painted drum head shows many figures in all five zones, as well as a celestial reindeer in the top section. 


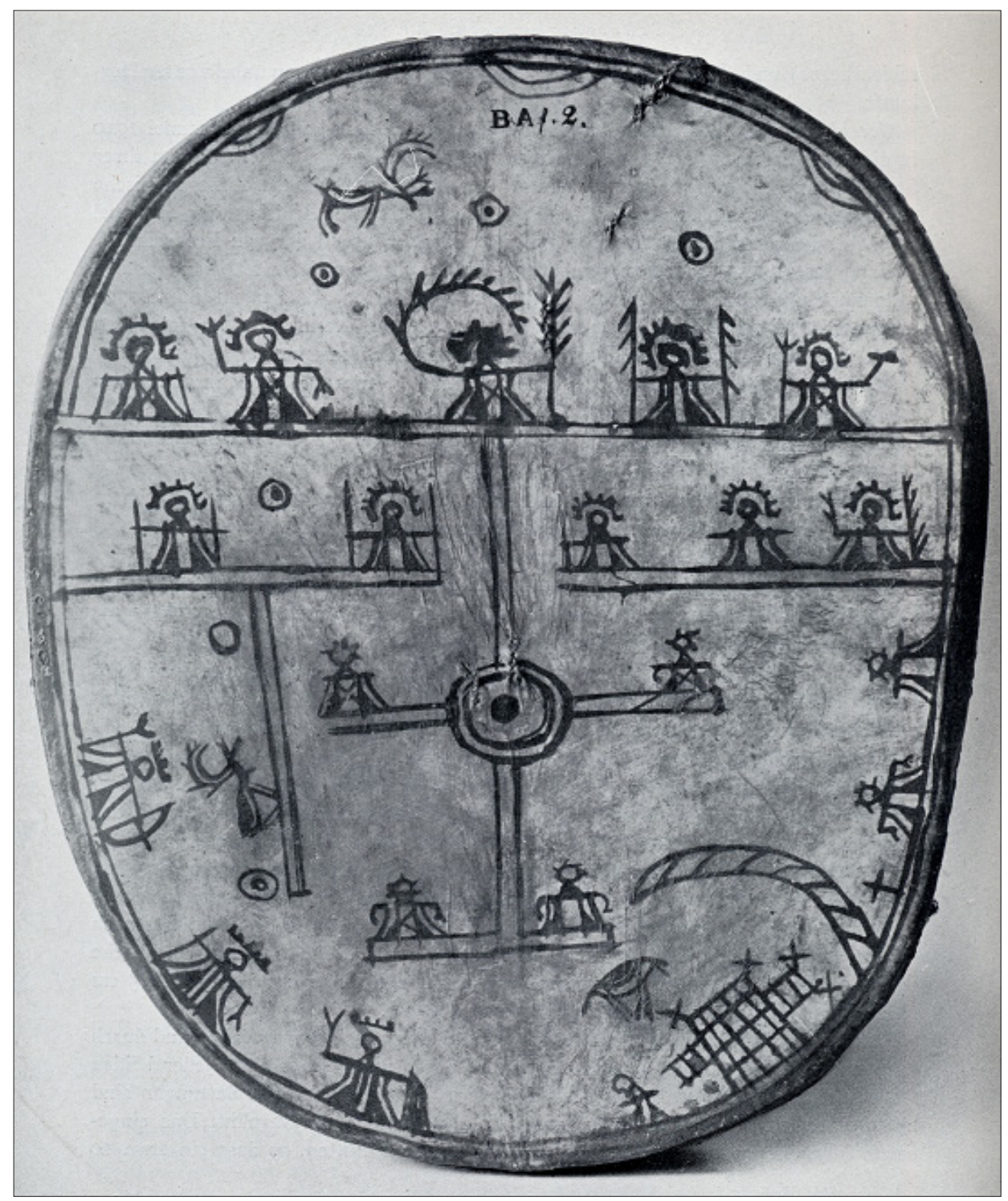

Figure 6a exhibits the rear view of the drum which has seven bear claws hanging from it that are amulets. Typically, bear hunting was done in the spring when the bears were waking up from hibernation. Sometimes the number of claws indicated the number of bears killed by the noaidi. According to Risto Pulkkinen, "The bear had a special cultic position in Saami culture. [...] The Saami consider all animals sacred...but the bear to be the most sacred of all. The bear was believed to come from the Säiva [the mythical underworld] (Pulkkinen 2005: 33). 


\section{NEW SÁMI DRUMS, NEW CONTEXTS, ILLUSTRATIONS AND DESIGNS}

Rock carvings, drum symbols, ornamentation on things like knives and spoons, and tin thread, embroidered ornamentation are forms of expression created by our forefathers to cover different needs. Rock carvings, drum symbols and ornaments are symbols that are tied to the spiritual. We regard these ornaments, drum symbols and rock carvings as a common heritage and property. [...] In other words, drum symbols, rock carvings and ornaments have been important in religious contexts; others have functioned as storytelling, while other symbols have had a decorative function. (Solbakk 2007: 79-80)

The five drums presented in this chapter are made by Elle-Maaret Helander. Each of the drum frames is made from "Aspen wood [and the frames have been covered with] reindeer skin that Elle-Maaret handles herself" (Helander 2011: 2 ). The coloured inks used in the decoration process of the skin are "acrylic, in addition to [dye from the alder tree which is used to colour the skins before painting. The basis for using the red dye is it helps to] bring up the Sámi spirit tradition [...]" (Helander 2011: 5-6). Through observation, it is apparent that the drums are of a frame type which is a new design, and both the techniques and materials used to decorate them with are also modern. In the creation of a new drum as the preparations are made for painting the skin "Elle-Maaret puts borders [around the edge of the drum first before painting the content inside]" (Helander 2011: 4). The motivation for making drums has several factors to it. The first which could be considered most important is that because of the dread installed into Sámi persons by the church, and the forbidding of traditional culture, Helander "[...] wants to take away the fear especially from the old Sámi people [...] even if she is considered a bit weird, she accepts it" (Helander 2011: 1). Prior to learning how to make drums, it was only as recent as "[...] in the 1990s, Elle Maaret started to get to know the old ways. The first push was that the daughters [who are musicians and performers], needed the drum" (Helander 2011: 2). Building drums and studying the culture has been an empowering experience as well as brought healing and a sense of reconnection to traditional ways, to what was previously forbidden within the culture. One of the traditional roles of the noaidi in Sámi society has been the artist and storyteller, where the application of images such as animals, human beings and spirits have emphasized the relationship with nature and the interconnectedness of life.

The inspiration for painting the drums with many of the symbols, some of which reflect the old hunting and fishing culture does according to Helander: 
[...] come from the spiritual world; about forty percent [...]. [Because] she does not want to copy the pictures [from elsewhere, the artist] creates her own pictures, and pictures come from stories [...] from the Sámi tradition, but Helander [also] creates her own images from her own beliefs and how she sees [...] [the spiritual dimensions in life [...]. (Helander 2011: 3)

The construction of drums in earlier times was an activity which took place amongst families in Lapland.

Decorations could signify affiliation with a particular group, or they could be purely ornamental. There are traces of ancient religion in modern superstitions connected with the acquisition of raw materials, the work or how the object is used or handled. These superstitions also included spells for ensuring success, and there are superstitions for avoiding bad luck. (Pulkkinen \& Kulonen \& Seurujärvi-Kari 2005: 76)

There are many old taboos and customs associated with shamanism with regard to the making of a new drum for an individual in relation to traditional shamanism in Lapland. During the interview, the question was asked from the author as to how members of Sámi society have reacted to her role as a drum maker with regard to the Witchcraft persecutions that have taken place previously and how the artist deals with the potential stigma which may arise as a result of her work. The response was as follows:

after an interview on the local Sámi radio, speaking about shamanism [when Helander] went to the city and was walking in the neighborhood and met her mother's relative, the relative [...] [moved far away to avoid contact] because she was afraid. [Elle Maaret] is considered a witch and that is [something bad in Lapland when viewed from within Sámi society due to legacy Christianity has left behind [...]. (Helander 2011: 7-8)

In Finland, most people are Laestadian's [Protestant, and therefore,] everything [...] [regarding] shamanism is a sin, [or] considered to be a sin [and] people are [...] brainwashed to be afraid of this old wisdom or ways; so when Elle-Maaret has come to old ways, people are [...] afraid of her. [...] Even if Helander believes in these shamanistic ways, it does not mean that she does not believe in God, because God is in the shamanism also. [In her own childhood home and upbringing the family] were Laestadian, [Protestant, however], not as most Laestadian, but really religious [where] all the old beliefs were sin so she did not hear them when she was a child. (Helander 2011: 1) 
Further questions were put forward in the interview regarding how interaction takes place with persons who ask for a drum to be made for them and how the symbols or content on the drum head is produced with reference to choices and motivation.

[...] when Elle-Maaret wanted to make a drum and she knows who the drum is for, she thinks about the person [as she is] making the drum; then the drum will have his/her energy also [...]. (Helander 2011: 3)

If the picture comes from somewhere else, from [...] [the clients] head or mine, then it is put together in a certain way. But if a picture comes from a story, it is put [...] [onto the] drum in the way the person understands it, or who buys [...] the drum. [Elle-Maaret] has to understand what the picture is about, so [it is essential] [...] the spiritual pictures are understandable; so the person [whom the drum is for] should [also] understand and get the idea of the name from the drum [as well]. (Helander 2011: 6)

The aforementioned references being made are with regard to symbols, human figures, animals and structures which are put into the content of the surface on the drum head.

The third research question was directed towards finding out how after a drum has been built, it becomes alive or empowered. With each drum, there is an information sheet which is provided that has

English instructions for this blessing ceremony. It is one Elle-Maaret has made [from] her own kind of blessing ceremony, because we cannot know how they have made [...] [the ceremony] in the old times. Some people who buy a drum [may] say it's a Witch drum, but I say it is not a Witch drum. It can be a Witch drum only if a Witch has blessed the drum for that purpose. [...] Everyone blesses their own drum to the purpose they use it; it can be blessed [...] [for] bad use or another. (Helander 2011: 3)

Additional information regarding the blessing or consecration of the drum also revealed the following.

When Elle-Maaret started to bless the drums she was combining different things, [...] [such as those] she read, and was [...] [deciding] what she wanted, what was needed to be in those drums. Of course, there are lots of Sámi ways, but also these universal [ones too] because all of the people who come to the workshops are not Sámi. (Helander 2011: 3-4)

The blessing and awakening of the drum is compared by Helander as "[...] like a couple's marriage ceremony [...]" (Helander 2011: 3). As a matter of respect 
for the work Elle Maaret does, the author has decided not to add the nature and content of the blessing ritual in the paper.

Below are the examples of Elle-Maaret's work presented through five photographs (Figures 7-11).

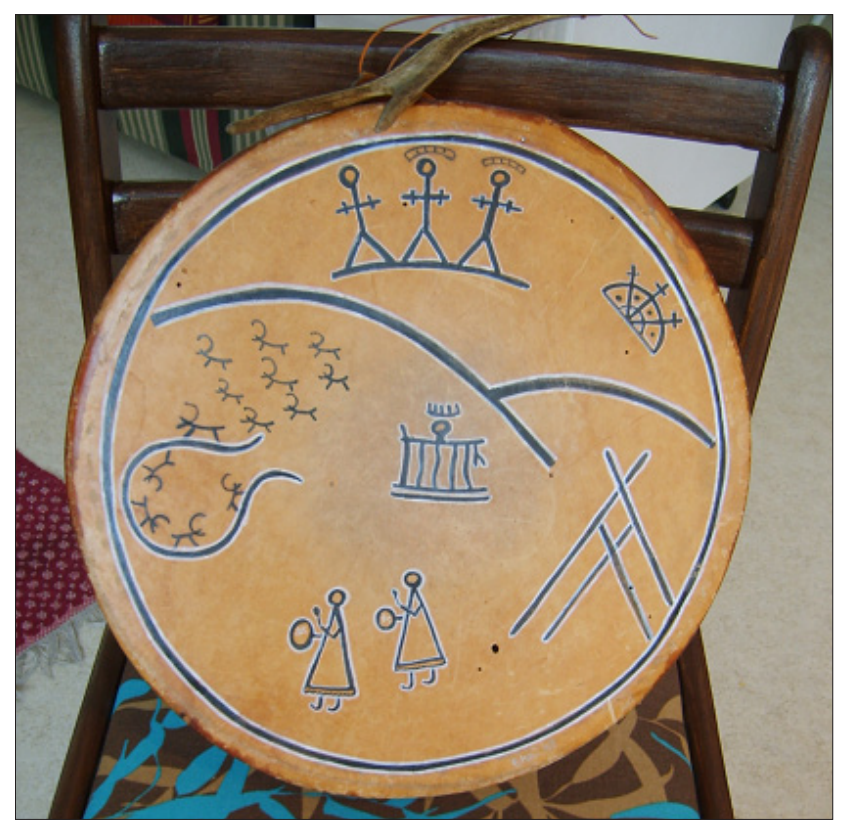

Figure 7. This is a picture of one of the first drums made to assist both daughters in their performances as singers and musicians. The content shows a combination of both Christian and Sámi figures.

The Holy Trinity at the top, with crowns is father and Holy Spirit, the son is the third figure. Sara-Akka is the mother figure [in the center]. Moon on the right side represents the sky. Reindeer represents reindeer herder's daughters. Reindeer also represents their father. A family portrait - two daughters pictured on the drum. (Helander 2011: 11) The border area just above the middle of the drum which stretches right across divides the drum into two segments, the upper world and the middle world. On top of the drum is a hammer made from reindeer antler which is used for playing the instrument. What is interesting about the content of this drum head for research purposes in relation to the artwork from the old drums influencing the new one above, is that similar features above the heads of the three deities on the drum head can also be recognized over the heads of deities on the old drum from the former Kemi Lappmark (Figure 5a) which presented above, thus demonstrating some level of influence. 


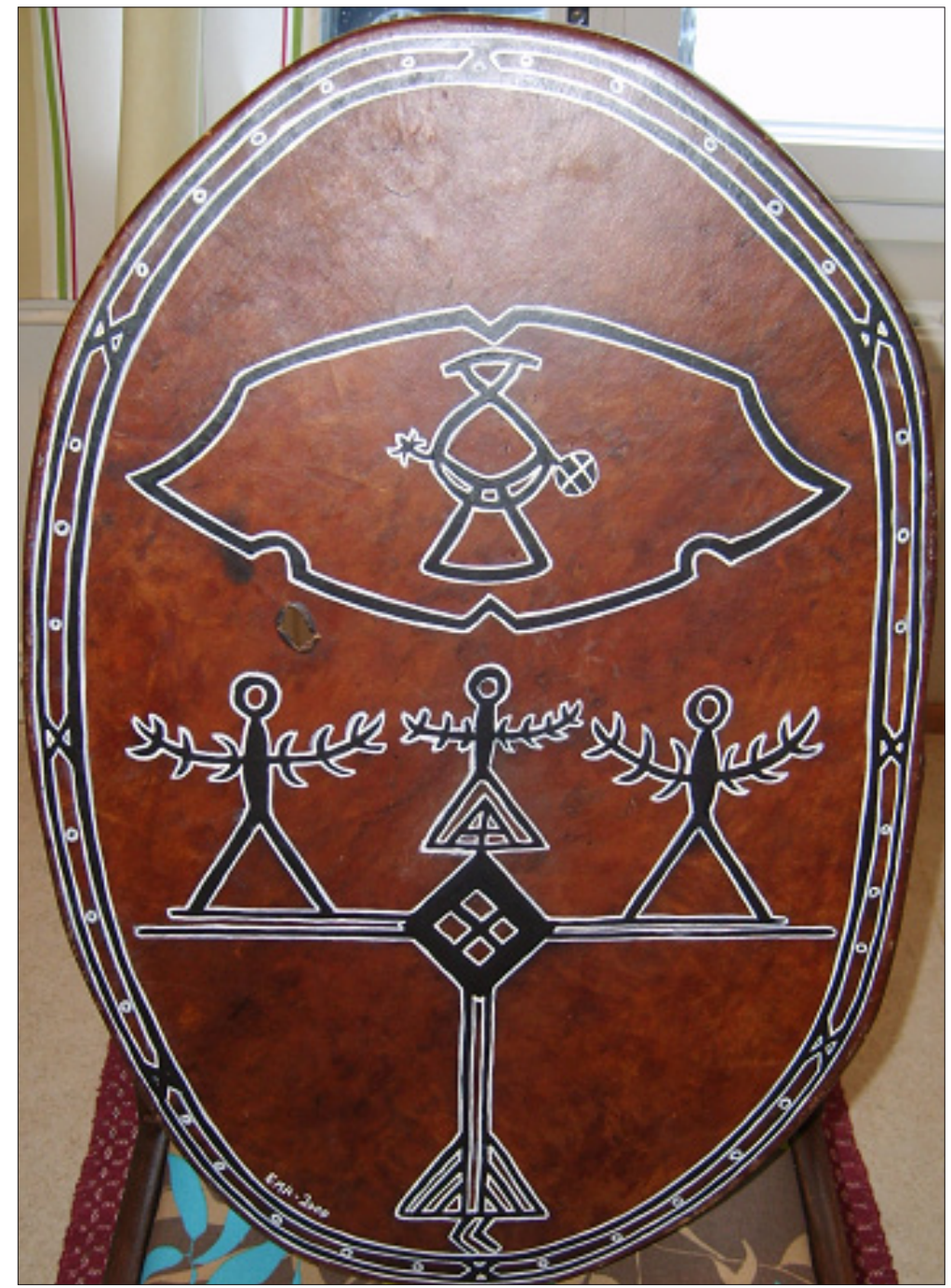

Figure 8. "The second drum has a reindeer mark as seen on the ear of a reindeer which is a personal symbol. Inside the ear is a shaman. [The] drum was made at a time when ElleMaaret was finding the spiritual path in Sodankyla. [This is a representation of a] more personal drum [which has a] sun symbol in the centre. On top of the sun-are weekend God's, middle is Sunday, left Friday, right Saturday. The shaman who is inside the ear is protecting the reindeers, and asks help from the weekend gods. These gods are from the lower heaven, Friday, Saturday, Sunday men, and sacred men” (Helander 2011: 11).

The marking of reindeer calf ears with a knife, means that a particular design is like a signature of hereditary ownership within families and organizations, and therefore the animals are recognisable thought their markings. 


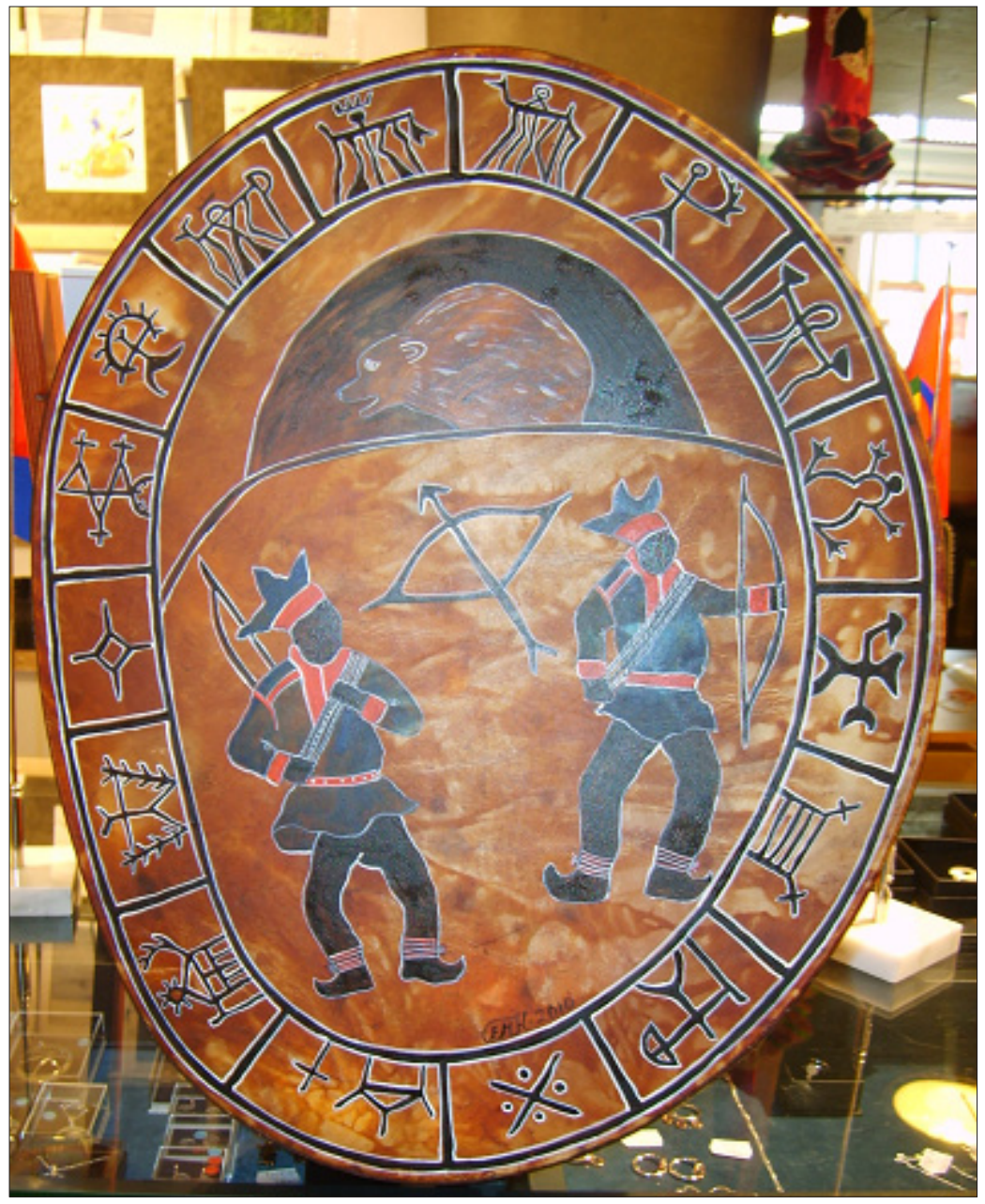

Figure 9. A decorated drum made by Elle-Maaret Helander on sale at the Siida museum, Inari. Central illustrations portray two Sámi men in their traditional costumes hunting a bear with bows and arrows. The presence of the bear in this picture highlights the value and importance the animal has for the Sámi. On the heads of the two hunters are hats with the four points (winds) on them. These designs were outlawed also by the church. Painted around the edge of the drum are many Sámi spirits and other symbols which represent the culture. At the top are three Goddess figures with their arms outstretched who appear to reflect similar Goddesses on the bottom section of the drum in Figure 6 above, showing again how historical art is utilized in this instance to decorate the new drum. 


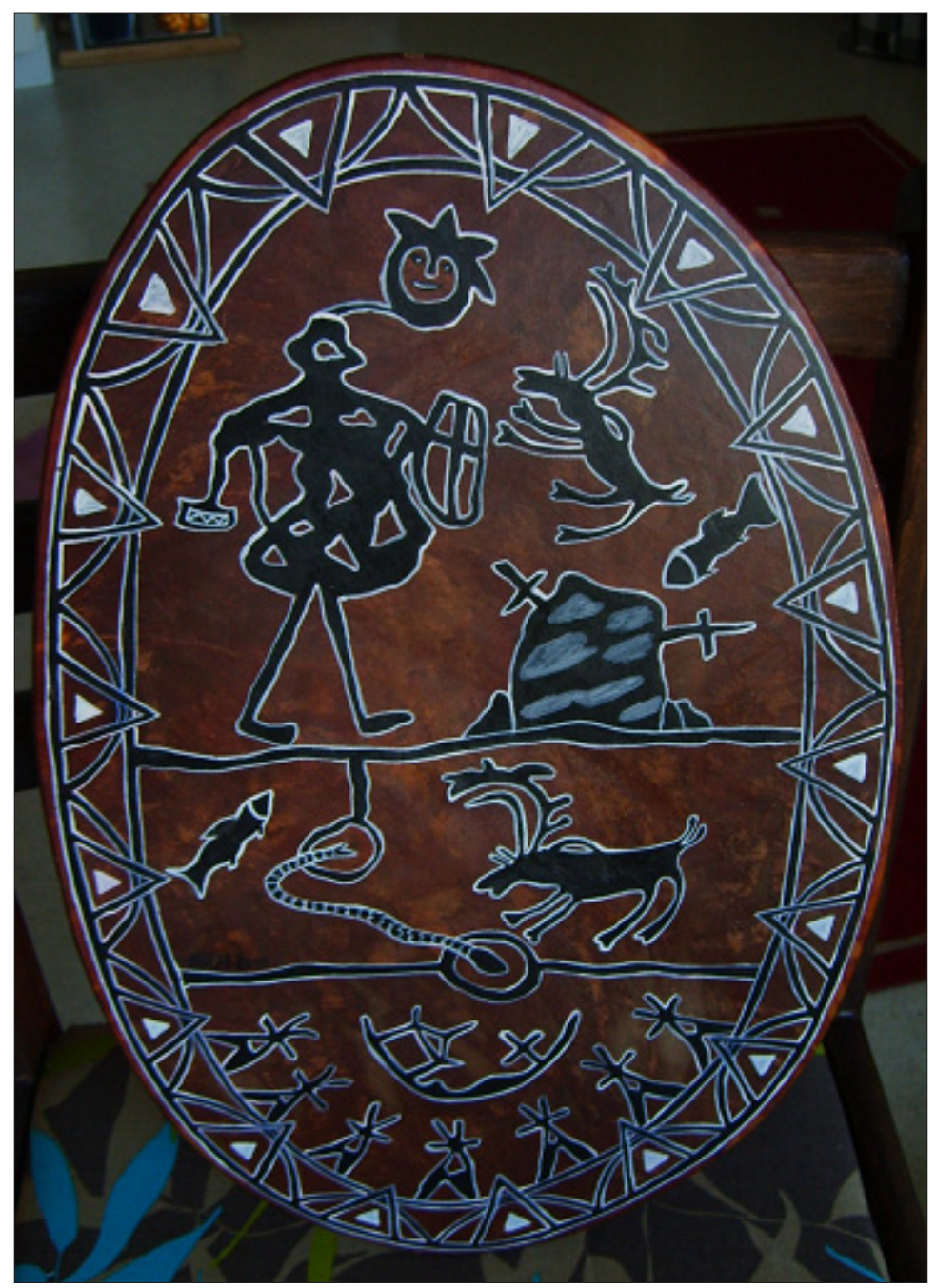

Figures 10 \& 10a, showing a drum which seems somewhat typical of the old Sámi drums that were usually oval in their shape. This one is divided into three segments: upper, middle and lower regions. The overall content of the drum:

depicts the story about a shaman who transforms himself [through a combination of rhythmic drumming and joiking] for example, into a snake and he also has a number of spiritual guides [which are animals seen here as a fish and reindeer, and the spirit of a holy boulder [called Sieidi in Sámi language]. Above his body is his free soul which looks like a combination of human and animal features. In his left hand he has a drum which is divided into four segments representing each of the four quarters and elements associated with each of these; in his right hand he holds a hammer which is 


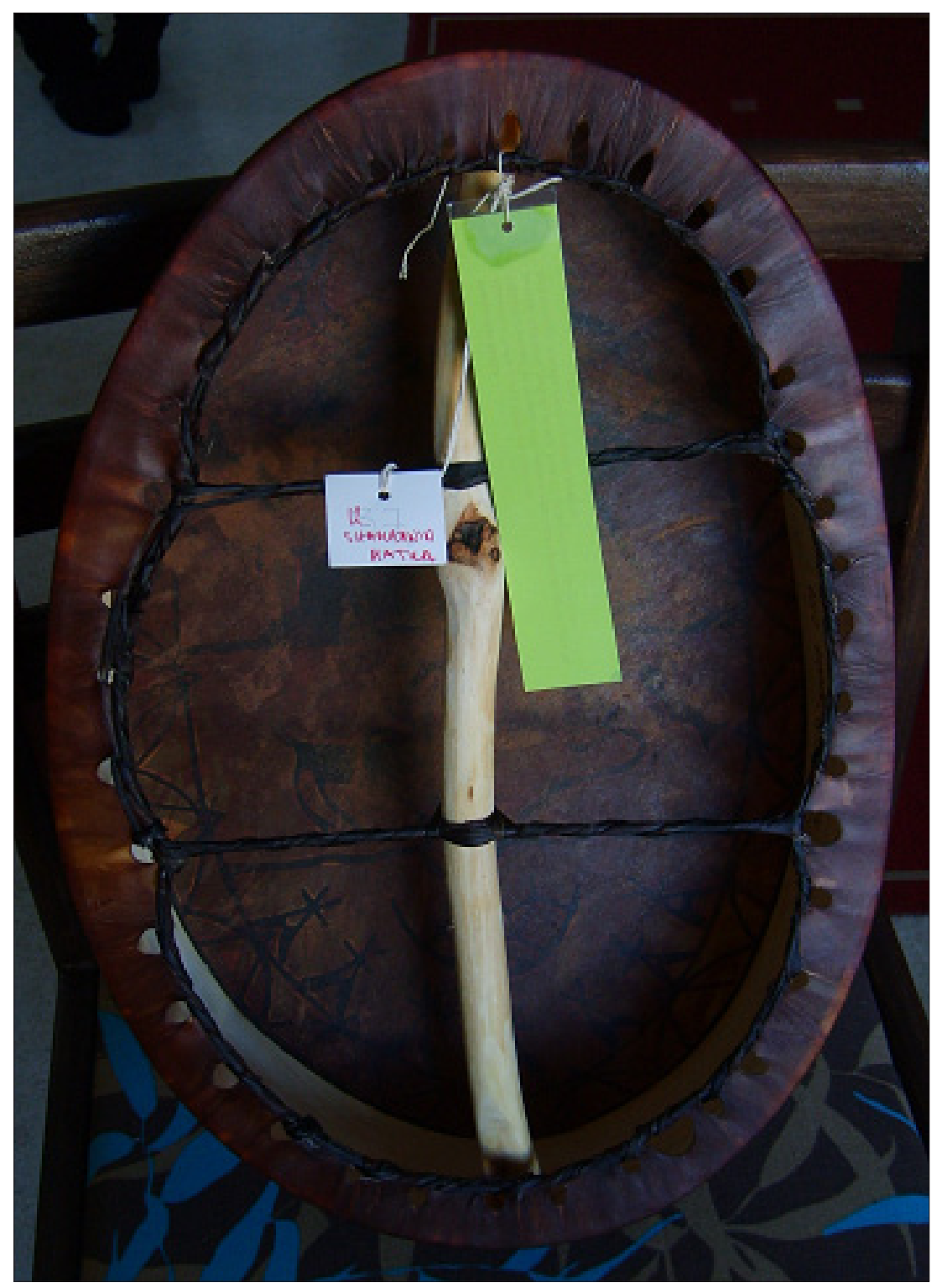

the instrument used to strike the drum with. [The next part of the ritual drama is where] the shaman shape-shifts into a snake and [the hole where] the shaman goes in to the lower world, extends from the middle world into the lower region, which is recognized by the Kota's and this is where the Sámi people live [in the afterlife]. Of course on the surface of the drum the space is limited so the artist cannot draw everything she sees but that's the content of her visionary work illustrated onto the skin where the shaman goes to the lower world to get knowledge. (Helander 2011: 6) 


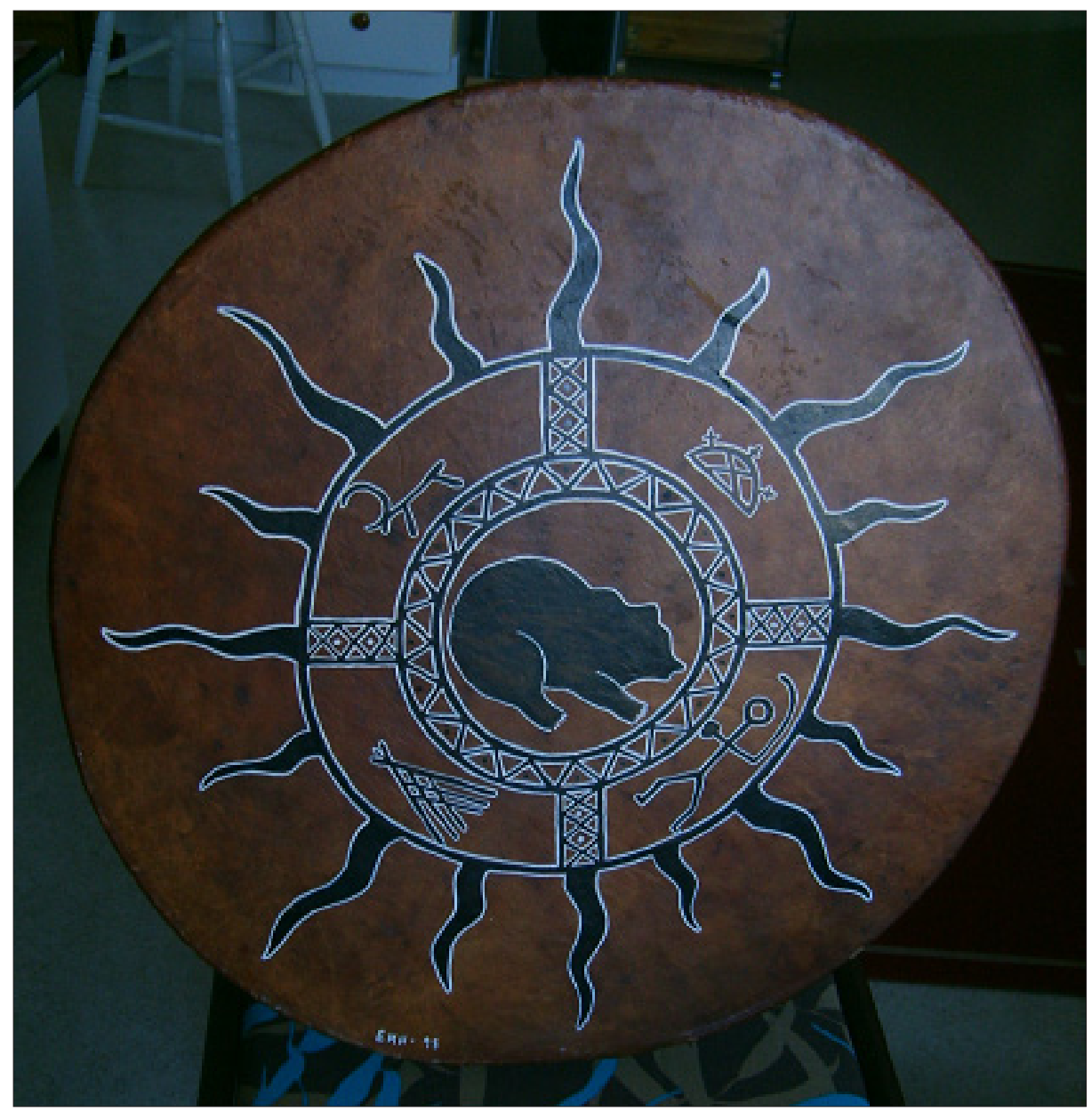

Figures $11 \& 11 a$. A drum with a bear in the centre.

Sun is in the centre divided into four sections, the bear is effecting everywhere in the world, going far beyond this world. The symbol with the [three] crosses [on it] are [the] moon. [The] bear is a symbol also of the great bear [or plough constellation which has a major influence on Arctic culture]. The four sections on the drum represent the four continents, meaning we are all the same, everyone has a dwelling. The man in the picture represents native medicine men-healers, kota [a sacred tent where shamans work]. Elle-Maaret wishes to symbolise all peoples or different races in harmony. Kota is a home for everyone, same sun for us all. Reindeer represents the animal kingdom. (Helander 2011: 11)

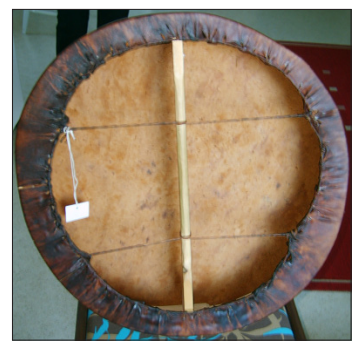




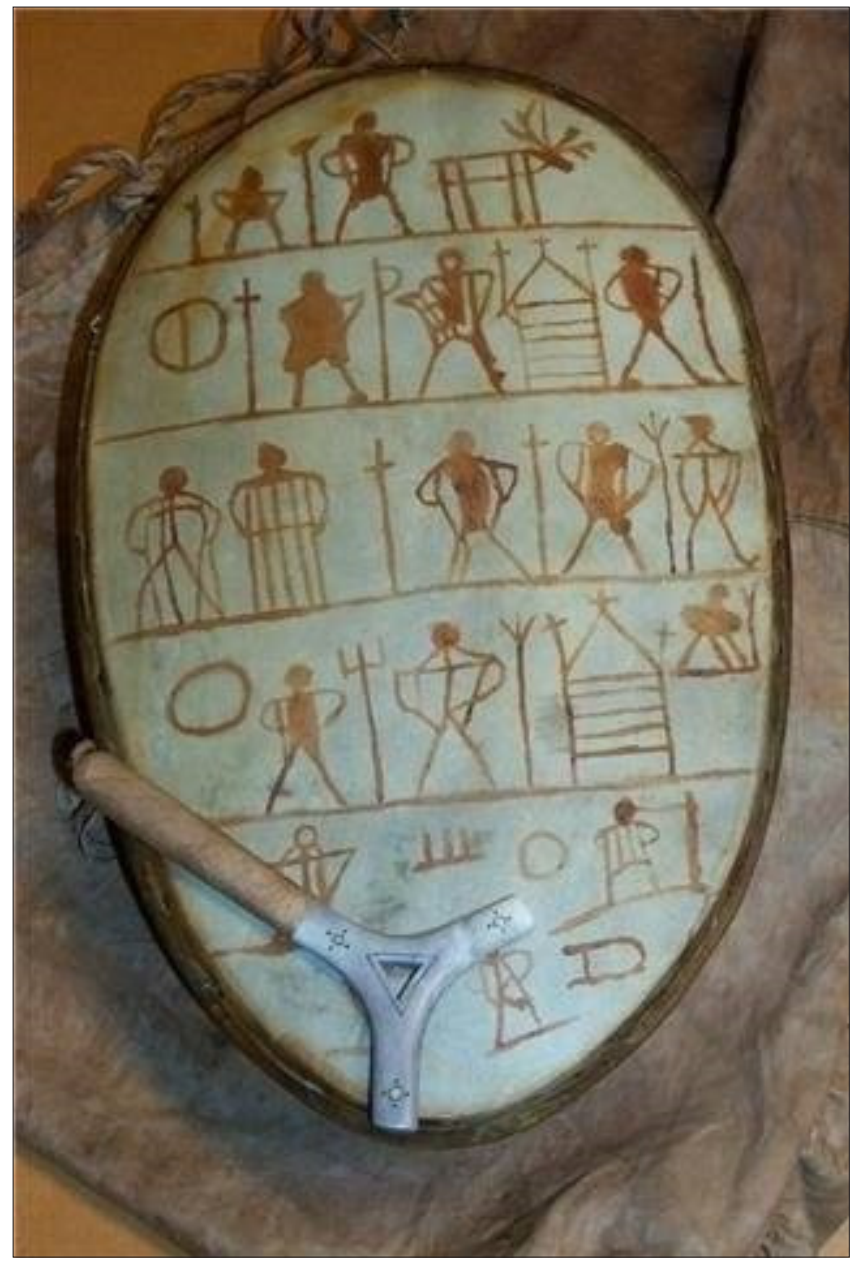

Figures $12 \& 12 a$. Two photographs of a replica of noaidi drum belonging to Anders Poulson in at the beginning of the seventeenth century from Finnmark. The drum was made by Ovlla Gaup from Kautokeino, Norway and was sold to the Alta Museum, Finnmark. The materials used in the construction of the drum are as follows:

the drum frame-bowl is made from birch gnarls [pahka in Finnish], which has been hollowed out and it is approximately $50 \mathrm{~cm}$ in height. This type of drum figured prominently in Norway in earlier times. The bone hammer is made from a combination of reindeer bone and birch wood. At the rear of the drum on the handle is a strip of decorative reindeer bone with traditional Sami patterns. The bronze ring is also included which was used as a pointer during divination by the noaidi. The symbolism and structural content on the drum head has been painted using red dye from the alder tree bark, which is the traditional substance used to paint drum with. (Gaup 2011) Photographs by Aslak Paltto 2011.

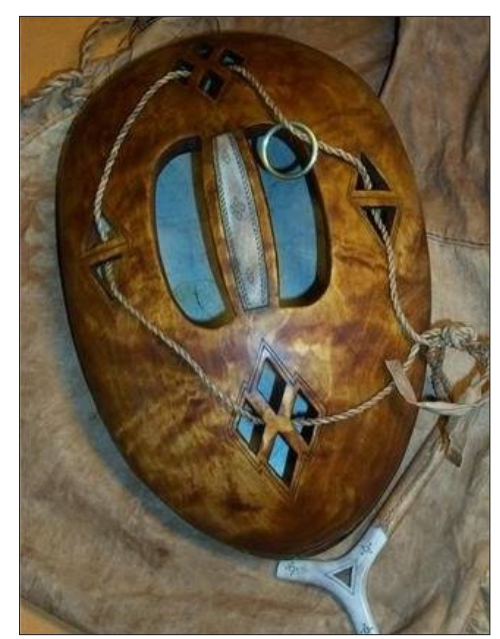




\section{CONCLUDING REMARKS}

The Analysis first and foremost shows that despite the cultural upheaval administered to the Sámi through colonialism by the church, that there are indeed elements of the old religion and culture which have survived. By contrast to the noaidi from the reindeer society three hundred years ago, the people today in Lapland who make drums and undertake healing work are referred to as shamans, a term which has originated in Siberia. The results of the study show that making drums for a Sámi person is a way of sustaining culture and to some extent cultural heritage and identity. The drum building process is also recognized as one way of overcoming and healing certain aspects of the past. The research presented above does not present any kind of definitive portrait of the practice of shamanism amongst the Sámi today in Lapland but does help to emphasize the influence which Sámi Pre-Christian religion plays in modern society.

Many of the drums made in earlier times were constructed from birch and pinewood. Aspen by comparison, is not very well known as a resource for drum making, but still used as a valuable material for construction. The reproduction of cultural symbols on contemporary drums moreover, emphasizes the importance of communication in the same way the old drums did. Both Gaup and Helander's handicraft productions clearly demonstrate the influence of the noaidi's art from the seventeenth and eighteenth centuries whereby, and despite the time span, modern drums do have importance as transmitters of culture, identity and worldview. In a broader sense, the new research shows how the production and analysis of modern Sámi shaman drums is one of the resources used for conducting research into aspects of Sámi religion and culture, thus providing insight and understanding into how the society also has its own heritage practices that help sustain the culture where symbols are used as mediums for communication.

The content of Helander's drums (Figures 8 and 9) which portray pictures of the central position of a shaman in each of the events is very interesting, because in each case the person stands out in world picture, thereby illustrating the role, position and importance of the shaman's status as in intermediary between the spirits and society as well as a protector. By contrast, from amongst the figures on drums 7 and 11 which does not include any shaman, the focus is more concerned with communication between the human world and spirits, thus emphasizing that a belief in the world of spirits still exists and is an important element in modern society in relation to art and expressing culture, whether taking care of family matters or petitioning for hunting luck. 
There is a variation between Gaup and Helander's work; meaning both have been influenced by historical symbolism, however, the fact Helander uses her intuitive faculties as well as the content of dreams and Sámi narratives is one way of combining old symbols with new ones. With regard to new drums emerging in Lapland, there are certain attitudes amongst people that are very mixed concerning how the drums are made and by who, which is beyond the scope of this paper. The outcome of the research overwhelmingly shows the value the use of symbols has in relation to drum making and cultural memory. Information in Ernst Manker's 1938 volume demonstrates that many noaidi in Lapland inherited the drums of their ancestors who taught them the craft of shamanizing; meaning they did not build their own. It would be ridiculous to believe that the drums build by Helander, by contrast, cannot be used shamanistically. In fact, one might consider the symbols painted on the drums and the ways in which the information has been received by the drum maker is in one way an effective method for helping create the right circumstances for persons with shamanic abilities to be effective in their workings.

A consecration ceremony used for awakening the drum and dedicating its purpose can be found in Uno Harva's book titled Lappalaisten Uskonto (1914), which means 'Lapps religion'. It may be the case, aspects of the dedicating ritual described in this book have influenced Helander in her work and that such has been the extent of colonialism throughout Lapland that these fragments are all which have survived. Having made this point, nothing remains the same, and therefore new types of drums indicates the adaptation to change which incorporates ancestral knowledge and wisdom into the artistic work of both Helander and Gaup. However, for persons from outside the culture to use the ritual for awakening the drum with regard to Sámi cultural practices seems somewhat controversial.

The fact Helander who could be viewed as an intercultural teacher does not commercialize the drums she makes is another feature of Sámi culture in relation to the ancient religion; signifying a certain level of respect for both the culture and ancestors as well as keeping the work within the ethical framework of Duodji traditional handicraft practices. It is true that many Sámi persons have been supportive of the reproduction of new drums which have been instrumental in allowing them to openly undertake healing work and break through the restrictions imposed on cultural practices for the past three hundred and fifty years in Lapland. Overall, the research shows that shamanism is still an integral part of the life and worldview of Sámi people today. 


\section{ACKNOWLEDGEMENTS}

I would like to express my thanks to the following people for their assistance in writing this paper: Elle Maaret Helander, Ovlla Gaup, Esa Marlisto, Jenni Laitinen, Joonas Vola, Jarmo Hörkkö, Lauri Ukkola and Martina Schäfer.

\section{NOTES}

1 Concerning alleviation of childbirth pains in women, in section $\mathrm{C}$ of Poulsen's drum which was divided into 5 sections, A,B,C,D,E, Maria is quoted as being "(Jumal Enne or Jumal Ache) - Mary, Christ's mother, God's woman. She helps with child-bearing woman and offers remission of sins" (Hagan 2005: 316). Poulsen was never sentenced for his involvement in so called sorcery; because he was murdered in jail.

\section{REFERENCES}

Ahlström, Gunnar 1971. Introduction. In: Schefferus, Johannes. The History of Lapland, wherein are shewed the original, manners, habits \&c. of that people, 1674. Stockholm: Suecica rediviva 22. Facsimile ed. Bokforlaget Rediviva.

Ahlbäck, Tore \& Bergman, Jan 1991. The Saami Shaman Drum. Based on Papers Read at the Symposium on the Saami Shaman Drum Held at Abo, Finland, on the 18th-20th of August 1988. Åbo: The Donner Institute for Research in Religion and Cultural History.

Autio, Eero 1995. Horned Anthropomorphic Figures in Finnish Rock-Paintings: Shamans or Something Else? Fennoscandia Archaeologica XII. http://www.sarks.fi/fa/PDF/ FA12_13.pdf last accessed April 24, 2013, pp. 13-18.

Bäckman, Louise 2004. The Noaidi and the Noaidi's Worldview: A Study in Sámi Shamanism from a Historical View Point. In: Elina Helander \& Tero Mustonen (eds). Snowscapes, Dreamscapes - Snowchange Book on Community Change. Vaasa: Fram Oy, pp. 30-36.

Berglund, Birgitta 2005. Recently Discovered Gievrie (South Saami Drums) Contexts, Meanings and Narratives. Acta Borealia, Vol. 22, No. 2, pp. 128-152. http://dx.doi.org/10.1080/08003835500327689, last accessed 8 June, 2013.

Gaski, Harald 1997. Sámi Culture in a New Era. http://www.utexas.edu/courses/sami/ diehtu/newera/gaski-newera.htm, last accessed 21 May, 2013.

Hagen, Rune 2006. Lapland. In: Richard M. Golden (ed.) Encyclopedia of Witchcraft; The Western Tradition Volume 3, K-P. United States of America ABS-CLIO, Inc., pp. 625-627.

Hagan, Rune 2005. Traces of Shamanism in the Witch Trials of Norway; The Trial of the Sámi Shaman Anders Poulsen. In: Hans de Waardt \& Jürgen Michael Schmidt \& H. C. Erik Midelfort \& Sönke Lorenz \& Dieter R. Bauer (eds.). Dämonische Besessenheit - Zur Interpretation eines kulturhistorischen Phänomens, Hexenforschung Band 9 (Hg.) Bielefeld: Verlag für Regional Geschichte, pp. 307-325. 
Harva, Uno 1915. Lappalaisten Uskonto. Porvoo: WSOY.

Holmberg, Uno 1964. The Mythology of All Races, in thirteen volumes. Finno-Ugric, Siberian - volume IV. New York: Cooper Square Publishers Inc.

Hultkrantz, Åke \& Bäckman, Louise 1978. Studies in Lapp Shamanism. Acta Universitatis Stockholmiensis Stockholm Studies in Comparative Religion. Stockholm: Almqvist and Wiksell International.

Hultkrantz, Åke \& Bäckman, Louise (eds.) 1985. Saami Pre-Christian Religion; Studies on the oldest traces of religion amongst the Saamis. Stockholm: Almqvist \& Wiksell International.

Hultkrantz, Âke 1983. Reindeer Nomadism and the Religion of the Saamis. In: B. R. Jonsson (ed.) ARV Scandinavian Yearbook of Folklore, Vol 39. Stockholm: The Royal Gustavus Adolphus Academy, pp. 11-26.

Itkonen, Toivo Immanuel 1943-1944. Suomen Lappalaisten Muinaisuskosta. [The Old Religion of the Lapps in Finland.] Kalevanseuran Vuosikirja, 24-24. Porvoo \& Helsinki: Werner Söderström Osakeyhtiö.

Joy, Francis 2011. The History of Lapland and the Case of the Sámi Noaidi Drum Figures Reversed. Folklore: Electronic Journal of Folklore, Vol 47, pp. 113-144. http://www.folklore.ee/folklore/vol47/joy.pdf http:// http://dx.doi.org/10.7592/FEJF2011.47.joy

Joy, Francis 2013. To All Our Relations: Evidence of Sámi Involvement in the Creation of Rock Paintings in Finland. Polar Record, First View Article. Cambridge, Cambridge University Press, pp. 1-4. http://dx.doi.org/10.1017/S0032247413000351

Keski-Santi, Jouko \& Lehtonen, Ulla \& Sivonen, Pauli \& Vuolato, Ville 2003. The Drum as Map: Western Knowledge Systems and Northern Indigenous Map Making. Imago Mundi, Vol. 55, No. 1, pp. 120-125. Routledge, Taylor \& Francis Group. http://dx.doi.org/10.1080/0308569032000097558, last accessed February 20, 2013.

Laestadius, Lars-Levi 2002. Fragments of Lappish Mythology. Juha Pentikäinen (ed.). Beaverton: Asaspia Books.

Lehtola, Veli-Pekka 2002. The Sámi People: Traditions in Transition. Aanaar \& Inari: Kustannus-Puntsi.

Linné, Carl Von 1732 [1965]. Carl Linnaeus Lapplandsresa. Stockholm.

Manker, Ernst Mauritz 1938. Die lappische Zaubertrommel. Eine ethnologische Monographie. 1, Die Trommel als Denkmal materieller Kultur. Acta Lapponica 1. Stockholm: Thule.

Manker, Ernst Mauritz 1950. Die lappische Zaubertrommel: eine ethnologische Monographie. 2, Die Trommel als Urkunde geistigen Lebens. Acta Lapponica 6. Stockholm: Gebers.

Mulk, Inga-Maria \& Bayliss-Smith, Tim 2007. Liminality, Rock Art and the Sami Sacred Landscape. Journal of Northern Studies, 1-2, pp. 95-122. http://www.diva portal. org/smash/get/diva2:442972/FULLTEXT01.pdf last accessed 26 January, 2013.

Nunez, Milton 1995. Reflections on Finnish Rock Art and Ethnohistorical Data. Fennoscandia Archaeologica XII, pp. 123-135. http://www.sarks.fi/fa/PDF/FA12_123. pdf last accessed on June 4, 2013.

Pentikäinen, Juha 1998. Shamanism and Culture. 3rd revised edition. Helsinki: Etnika. Pulkkinen, Risto \& Kulonen, Ulla-Maija \& Seurujärvi-Kari, Irja 2005. The Saami. A Cultural Encyclopedia. Helsinki: Finnish Literature Society (SKS Kirjat). 
Schefferus, Johannes 1674. The History of Lapland, wherein are shewed the original, manners, habits \&c. of that people. Suecica Rediviva 22. Facsimile ed. Stockholm: Bokforlaget Rediviva, 1971.

Schefferus, Johannes 1673. Joannis Schefferi Argentoratensis Lapponia. (Latin edition.) Frankfurt am Main \& Leipzig: Martin Wallerborden/Buchhåndlern.

Solbakk, Aage 1990. The Sámi People. Karasjok: Sámi Instituhtta.

Solbakk, John T. 2007. Traditional Knowledge and Copyright. Vaasa: Waasa Graphics Oy.

Sommarström, Bo 1991. The Saami Shaman's Drum and the Star Horizons. In: Tore Ahlbäck \& Jan Bergman (eds.) The Saami Shaman Drum. Based on Papers Read at the Symposium on the Saami Shaman Drum Held at Åbo, Finland, on the 18th-20th of August 1988. Abo: The Donner Institute for Research in Religion and Cultural History, pp. 136-169.

Zachrisson, Inger 1991. The Saami Shaman Drums: Some Reflections from an Archaeological Perspective. In: Tore Ahlbäck \& Jan Bergman (eds.) The Saami Shaman Drum. Based on Papers Read at the Symposium on the Saami Shaman Drum Held at Abo, Finland, on the 18th-20th of August 1988. Abo: The Donner Institute for Research in Religion and Cultural History, pp. 80-95.

\section{INTERVIEW MATERIAL}

Helander, Elle-Maaret 2011. The story of a Sámi Drum Maker. Translated from Finnish to English by Jenni Laitinen. Pyhätunturi Pyhäjärvi-Lapland, Finland, pp. 1-12.

Paltto, Aslak 2011. Interview with a Sámi journalist and Drum Maker. Inari-Lapland, Finland, pp. 1-9

Ukkola, Lauri 2011. Interview with a Lapland Shaman. Translated from Finnish to English by Jarmo Hörkkö. Sodankyla-Lapland, Finland, pp. 1-10

\section{TELEPHONE INTERVIEWS}

Gaup, Ovlla 2011 \& 2013. Telephone interview with author. October 12, 2011 and September 28, 2013. p. 1.

Marlisto, Esa 2013. Telephone interview with the author. Translated from Finnish to English by Joonas Vola, June17, 2013, pp. 1-3. 